\title{
THE NEGATIVE IMPLICATIONS OF THE COMMERCE CLAUSE*
}

\author{
JoHN B. SHOLLEY $\dagger$
}

$\mathrm{O}$ N MARCH 4, I935, the United States Supreme Court held in Baldrein v. Seelig that the state of New York had no power to protect its milk producers against underselling by the producers of other states even though the former were by law forbidden to sell below prescribed prices, ${ }^{2}$ and the resulting competition would go far to wreck the whole statutory system. The particular statute condemned forbade in effect the sale of imported milk in New York unless its producers had been paid the equivalent of the New York standard price. The gist of the opinion of Mr. Justice Cardozo is contained in the following excerpts:

If New York, in order to promote the economic welfare of her farmers, may guard them against competition with the cheaper prices of Vermont, the door has been opened to rivalries and reprisals that were meant to be averted by subjecting commerce between the states to the power of the nation. ${ }^{3}$

What is ultimate is the principle that one state in its dealings with another may not place itself in a position of economic isolation. Formulas and catchwords are subordinate to this overmastering requirement. Neither the power to tax nor the police power may be used by the state of destination with the aim and effect of establishing an economic barrier against competition with the products of another state or the labor of its residents. Restrictions so contrived are an unreasonable clog upon the mobility of commerce. They set up what is equivalent to a rampart of customs duties designed to neutralize advantages belonging to the place of origin. They are thus hostile in conception as well

* The title was suggested by Professor Malcolm P. Sharp of the University of Chicago Law School who furnished many other valuable suggestions and criticisms, both in person and through the medium of his article, Movement in Supreme Court Adjudication, 46 Harv. L. Rev. 593-6ro, 623-25 (I933). For other discussions of the subject-matter of this paper, see Reynolds, The Distribution of Power to Regulate Interstate Carriers between the Nation and the States 76-II6, I47-55 (I928); Prentice and Egan, The Commerce Clause I-42 (I898); Gavit, The Commerce Clause I-3I (I932).

† Assistant Professor of Law, University of Washington; Raymond Fellow, University of Chicago Law School, I935-36.

I 294 U.S. 5 II (I935).

2 The purely intrastate features of the New York Milk Control Act were held constitutional in Nebbia v. New York, 29r U.S. 502 (I934) and Hegeman Farms Corp. v. Baldwin, 293 U.S. I63 (I934). The act set up administrative machinery with authority to fix a scale of minimum prices from producer to consumer. It was upheld as a reasonable means of promoting the economic welfare of a paramount industry of the state and of protecting the health of the public.

3 Baldwin v. Seelig, 294 U.S. 5II, 522 (I935). 
as burdensome in result. The form of the packages in such circumstances is immaterial, whether they are original or broken. The importer must be free from imposts framed for the very purpose of suppressing competition from without and leading inescapably to the suppression so intended.4

It is one thing for a state to exact adherence by an importer to fitting standards of sanitation before the products of the farm or factory may be sold in its markets. It is a very different thing to establish a wage scale or a scale of prices for use in other states, and to bar the sale of the products, whether in the original packages or in others, unless the scale has been observed. 5

Just a year later, on March 2, r936 the Supreme Court held in Whitfield v. Ohio ${ }^{6}$ that the state of Ohio had the power to prohibit the sale of convictmade goods within its borders whether imported or not, at least when sanctioned by Congress. ${ }^{7} \mathrm{Mr}$. Justice Sutherland's opinion contained the following passages:

The view of the state of Ohio that the sale of convict-made goods in competition with the products of free labor is an evil, finds ample support in fact and in the similar legislation of a preponderant number of the other states. Acts of Congress relating to the subject also recognize the evil. . . . .

All such legislation, state and federal, proceeds upon the view that free labor, properly compensated, cannot compete successfully with the enforced and unpaid or underpaid convict labor of the prison. A state basing its legislation upon that conception has the right and power, so far as the federal Constitution is concerned, by non-discriminating legislation, to preserve its policy from impairment or defeat, by any means appropriate to the end and not inconsistent with that instrument. The proposition is not contested that the Ohio statute would be unassailable if made to take effect after a sale in the original package. And the statute as it now reads is equally unassailable, since Congress has provided that the particular subjects of interstate commerce here involved "shall be governed by a rule which divests them of that character at an earlier period of time than would otherwise be the case," In re Rahrer (I40 U.S. 545, 562) namely upon arrival and delivery.

.... Even without such action by Congress the unbroken-package doctrine, as applied to interstate commerce, has come to be regarded, generally at least, as more artificial than sound. ${ }^{8}$

The clear inference is that the result would have been the same in the absence of the Act of Congress. No mention whatsoever was made of Baldwin

4Id. at 527 (italics added). ${ }^{5} I d$. at 528 .

${ }^{6}{ }^{6}$ Sup. Ct. 532 (1936). For further comment on this case, see note, Power of Congress to Subject Interstate Commerce to State Regulation, post, p. 636 .

7 The Hawes-Cooper Act, 45 Stat. I084 (r929), 49 U.S.C.A. $\$ 60$ (I935), passed Jan. I9, I929 and effective Jan. I9, I934, provides that all convict-made goods shall be subject to the laws of a state upon arrival and delivery therein for use, sale, or storage to the same extent as though such goods had been produced therein and shall not be exempt by reason of being introduced or sold in the original package.

${ }^{8}$ Whitfield v. Ohio, $5^{6}$ Sup. Ct. 532, 535 (1936) (italics added). 
v. Seelig, yet Mr. Justice Cardozo was one of the six justices subscribing to the opinion. 9

Rarely, if ever, has the Supreme Court delivered opinions as inconsistent in tenor as these two within such a short space of time. The actual holdings of the two cases can perhaps be reconciled-this point will be dealt with later-but not on the reasoning contained in the opinions. We are not told why the "ultimate principle" and "overmastering requirement" which moved the Court to strike down the New York statute were not equally effective in the Whitfeld case. Surely a Constitution which expressly sanctioned the institution of human slavery for seventy-six years cannot now be read as outlawing all prison industry and excluding the products thereof from the protection afforded other property. ${ }^{\text {To }}$ The reason lies deeper. The inconsistency in the opinions results from different constructions of the Constitution itself-specifically, of the commerce clause as a limitation on state power.

The negative implications of the commerce clause have always troubled the Supreme Court. Not only has there been the usual difficulty involved in applying a general principle to varying factual situations, but there has been radical disagreement as to the fundamental principle itself. Many doctrines and formulas have been advanced from time to time with varying success, but none has been suggested at once broad enough to comprehend the results which the Court has reached and definite enough to be of much value in forecasting future decisions. The Supreme Court has, it would appear, frequently pursued the policy of deciding the case before it in accordance with its conception of what the national welfare requires, then rationalizing and, when possible, reconciling its decision with the language used in prior opinions. That such is the present policy of the Court is demonstrated by the two cases mentioned above.

Although from the standpoint of the businessman and the statesman this pragmatic handling of one of the most difficult problems arising from our federal system has been on the whole a success, it does not satisfy the constitutional theorist who professes to believe that the Supreme Court is mechanically separating the sheep from the goats by applying an unchanging and unambiguous constitutional standard to acts of legislation, ${ }^{\text {II }}$

9 Justices Van Devanter, McReynolds, and Stone concurred in the result in the Whitfield case, without indicating wherein they differed from the reasoning of Justice Sutherland.

ro See the remarks of McLean, J. in Groves v. Slaughter, 5 Pet. (U.S.) 449, 507-8 (I84r), and those of Baldwin, J., id. at 5I3.

II Justice Roberts is one of the leading exponents of this view. Railroad Retirement Bd. v. Alton R. Co., 295 U.S. 330, 346 (1935); United States v. Butler, 56 Sup. Ct. 3I2, 318 (1936). 
nor the traditional common lawyer who believes that certainty and continuity in the law are indispensable. Moreover, the refusal of the Supreme Court to follow its own lead, or, rather, to select finally one or the other of competing principles, makes it impossible for legislative bodies, the lower courts, and attorneys to forecast its attitude on novel legislation and guide themselves accordingly. Despite its modest professions to the contrary the Supreme Court has always played a large part in directing the development of statutory law by pointing out the directions in which it will be permitted to grow. The satisfactory performance of this important function demands consistency at least in the selection of fundamental principles, if not in their application.

It is the purpose of this paper to sketch in broad outline the judicial history of the commerce clause as a limitation on the powers of the states. From the outset there have been two competing principles. The one is that the Constitution itself denies to the states all power to regulate interstate and foreign commerce, herein referred to as the exclusive theory; the other is that the states retain their powers in respect to those subjects until Congress supersedes their authority by an exercise of its superior power, ${ }^{\mathrm{T} 2}$ herein called, inaccurately, the concurrent theory. Although both theories contemplate a rather extensive curtailment of the power of the states to regulate the conduct of interstate and foreign commerce, they differ as to which organ of the federal government, the Supreme Court or Congress, shall define the sphere of state power. A number of syntheses and compromises have been advanced from time to time, but the underlying conflict has persisted.

\section{THE CONSTITUTION}

There can be no doubt that two of the chief defects of the Articles of Confederation were the lack of power in Congress to regulate foreign and interstate commerce, and the presence of power in the various states to do so. The results were inability to present a united front to foreign nations and the existence of commercial rivalries and reprisals at home. ${ }^{13}$ The desire to remedy these evils was probably the chief motive for calling the

${ }^{2}$ The closely allied problem of determining how far congressional legislation supersedes state legislation not actually inconsistent therewith, the so-called "occupation of the field" doctrine, is beyond the scope of the present inquiry. For early judicial discussions, see Houston v. Moore, 5 Wheat. (U.S.) I (I820); Prigg v. Pennsylvania, I6 Pet. (U.S.) 539 (I842). For recent discussions, see Gavit, op. cit. supra note*, 247-264; Grant, The Scope and Nature of Concurrent Power, 34 Col. I. Rev. 995, rorg-23 (1934).

${ }^{13}$ Hamilton, The Federalist, nos. 7 , II, 22; Madison, id., no. 42. Johnson, J., in Gibbons v. Ogden, 9 Wheat. (U.S.) I, 224-5 (I824); Marshall, C. J., in Brown v. Maryland, I2 Wheat. (U.S.) 4I9, 445-6 (I827); 2 Story, Commentaries on the Constitution 504-6 (I833). 
Convention of $I 787 .{ }^{14}$ But it does not follow that once the framers met to draft the new plan of government the subject of commercial regulation was foremost in their minds, ${ }^{15}$ or that this factor was of controlling force in securing the adoption of the Constitution. ${ }^{{ }^{6}}$ Much less is one warranted in jumping to the conclusion that the Constitution as drafted and adopted necessarily foreclosed all possibility of the recurrence of those evils which caused the abandonment of the Articles of Confederation. The primary source for the determination of the purpose and the effect of any legal document is the words contained therein. In the language of Chief Justice Marshall:

.... although the spirit of an instrument, especially of a constitution, is to be respected not less than its letter, yet the spirit is to be collected chiefly from its words. It would be dangerous in the extreme to infer from extrinsic circumstances, that a case for which the words of an instrument expressly provide, shall be exempted from its operation. Where words conflict with each other, where the different clauses of an instrument bear upon each other, and would be inconsistent, unless the natural and common import of words be varied, construction becomes necessary, and a departure from the obvious meaning of words is justifiable. But if, in any case, the plain meaning of a provision, not contradicted by any other provision in the same instrument, is to be disregarded, because we believe the framers of that instrument could not intend what

14 See I Elliot, Debates on the Federal Constitution I22-55 (2d ed. 1836 ) for the steps leading to the calling of the Convention. "Before the Constitution existed, the States taxed the commerce and intercourse of each other. This was the leading cause of abandoning the Confederation and forming the Constitution,-more than all other causes it led to the result." Catron, J., in Passenger Cases, 7 How. (U.S.) 283, 445 (1849).

${ }_{75}$ There was very little debate on the clauses relative to commercial regulation. See Warren, Making of the Constitution $567-89$ (r928). There was some reluctance on the part of southern delegates to vest the power in Congress. Id. at 580 et seq. Cf. Madison's statement in The Federalist, no. 45: "The regulation of commerce, it is true, is a new power [of Congress]; but that seems to be an addition which few oppose, and from which no apprehensions are entertained."

${ }^{26}$ "The principal purposes to be answered by union are these: The common defence of the members; the preservation of the public peace, as well against internal convulsions as external attacks; the regulation of commerce with other nations, and between the states; the superintendance of our intercourse, politics and commercial, with foreign countries." Hamilton, The Federalist, no. 23. Madison's listing of the chief powers conferred on the new federal government gave the commerce power a more prominent place. $I d$., no. 4I. There appears to have been little debate on the subject in the ratifying conventions, probably because, as Madison suggests, there was general agreement that national control was necessary. There were some misgivings, however, in the southern states. An amendment was proposed by both the Virginia and North Carolina conventions to require a two-thirds vote in each house of Congress to enact commercial regulations. 3 Elliot, Debates $65 \circ ; 4$ id. at $24 \mathrm{I}$.

"If there was any one object riding over every other in the adoption of the constitution, it was to keep the commercial intercourse among the States free from all invidious and partial restraints." Gibbons v. Ogden, 9 Wheat. (U.S.) I, $23 x$ (I824), per Johnson, J. This statement seems unduly broad. 
they say, it must be one in which the absurdity and injustice of applying the provision to the case, would be so monstrous, that all mankind would, without hesitation, unite in rejecting the application. ${ }^{\text {I7 }}$

The Tenth Amendment provides: "The powers not delegated to the United States by the Constitution, nor prohibited by it to the States, are reserved to the States respectively, or to the people." The inquiry is thus twofold: first, a determination of the extent to which the states are expressly forbidden to regulate interstate and foreign commerce; and second, a determination of the extent to which the delegation of commercial power to Congress impliedly divests the states of power.

Certain subjects of importance to the commercial interests of the country are absolutely removed from state control. "No State shall enter into any Treaty, Alliance, or Confederation; . . . . coin Money; emit Bills of Credit; make any Thing but gold and silver Coin a Tender in Payment of Debts; pass any . . . . Law impairing the Obligation of Contracts." "I8 In certain other respects the states are forbidden to act in a manner inconsistent with the ideal of national unity. "Full Faith and Credit shall be given in each State to the public Acts, Records, and Judicial Proceedings of every other State. And the Congress may by general Laws prescribe the Manner in which such Acts, Records and Proceedings shall be proved, and the Effect thereof." "The Citizens of each State shall be entitled to all Privileges and Immunities of Citizens in the several States." presence of these specific prohibitions suggests certain questions: Why, if the framers intended to exclude the states from the regulation of interstate and foreign commerce, did they not do so expressly?2I Why were not the products of other states, as well as their citizens, expressly protected from discriminatory state action? One possible answer is that the framers were naturally reluctant to circumscribe the sphere of state action too

${ }_{77}$ Sturges v. Crowninshield, 4 Wheat. (U.S.) I22, 202-3 (I8I9). See also Dartmouth College v. Woodward, 4 Wheat. (U.S.) 518, 644-5 (I8I9), per Marshall, C. J.; Addyston Pipe \& Steel Co. v. U. S., I75 U.S. 2II, 227-8 (I899), per Peckham, J. But of. Fletcher v. Peck, 6 Cranch (U.S.) 87, I37 (I8IO), per Marshall, C. J., and id. at I44-5, per Johnson, J.

$$
{ }^{8} \text { U.S. Const., art. I, § I0, cl. x. } \quad \text { I9 Id., art. 4, § r. } \quad{ }^{20} I d . \text {, art. 4, § 2, cl. I. }
$$

2I Warren, op. cit. supra note 15 , at 570 , states that the question as to the exclusiveness of the commercial power of Congress was not foreseen by the framers. "At the formation of the Constitution, the power to regulate commerce attracted but little attention, compared with that to impose duties on imports and tonnage; and this last had caused so much difficulty, both at home and abroad, that it was expressly and entirely taken away from the States, but the former was not attempted to be. The former, too, occupies scarce a page in The Federalist, while the latter engrosses several numbers. A like disparity existed in the debates in the Convention, and in the early legislation of Congress. Nor did the former receive much notice of the profession in construing the Constitution till after a quarter of a century." Passenger Cases, 7 How. (U.S.) 283,545 (1849), per Woodbury, J. 
sharply in advance of any experience under the new system. Another is that such patently extensive restrictions on the "sovereign" states would have jeopardized the chance of adoption.

Next there are a group of conditional restraints on state power. "No state shall, without the Consent of the Congress, lay any Imposts or Duties on Imports or Exports, except what may be absolutely necessary for executing its inspection Laws: and the net Produce of all Duties and Imposts, laid by any State on Imports or Exports, shall be for the Use of the Treasury of the United States; and all such Laws shall be subject to the Revision and Controul of the Congress." "No State shall, without the Consent of Congress, lay any Duty of Tonnage, . . . . or enter into any Agreement or Compact with another State, or with a foreign Power." ${ }^{\prime 23}$ It was the exercise of these powers which aroused the greatest dissatisfaction under the Articles of Confederation. Hence it might reasonably be argued that in all other respects the states were left free to regulate interstate and foreign commerce. Chief Justice Marshall, however, pointed out that these limitations, except of course the last, are imposed on the taxing power of the states, a power obviously not surrendered, and therefore it was necessary to set them out in detail. ${ }^{24} \mathrm{~A}$ more difficult argument for the proponents of the exclusive theory to refute is that the delegation to Congress of supervisory power over the matters of state commercial compacts and duties on imports, exports and tonnage is a clear indication that Congress was intended to exercise a similar control over other state powers whose exercise affects interstate and foreign commerce, the difference being that in respect of the matters listed in the second and third clauses of Article Ten, the silence of Congress must be construed as a denial of permission to the states to act, whereas in respect of other matters less likely to burden commerce its silence is of no effect, leaving the states free to act. ${ }^{25}$ The answer of Justice Johnson to this contention, that the clauses in question define the limits within which Congress may consent to state action, seems somewhat strained. ${ }^{26}$

$$
22 \text { U.S. Const., art. I, § Io, cl. } 2 . \quad 23 I d \text {., art. I, § Io, cl. } 3 .
$$

${ }^{24}$ Gibbons v. Ogden, 9 Wheat. (U.S.) I, 200-3 (1824). But cf. p. 572 infra. For support for the proposition that the taxing and commercial powers are distinguished throughout the Constitution see 2 Tucker, The Constitution of the United States 520-3 (I899). (I849).

${ }_{25}$ See remarks of Woodbury, J. along this line. Passenger Cases, 7 How. (U.S.) 283, 558

26 "But this whole clause, as to these two subjects, appears to have been introduced $e x$ abundanti cautela, to remove every temptation to an attempt to interfere with the powers of Congress over commerce, and to show how far Congress might consent to permit the States to exercise that power. Beyond those limits, even by the consent of Congress, they could not exercise it." Gibbons v. Ogden, 9 Wheat. (U.S.) I, 237 (1824). 
Two of the clauses limiting the commercial power of Congress have some bearing on the question under discussion. "No Preference shall be given by any Regulation of Commerce or Revenue to the Ports of one State over those of another." ${ }^{27}$ It has been urged ${ }^{28}$ that this provision forbids all state regulations of navigation which would destroy the uniformity contemplated by the Constitution. It is now well settled, however, that this clause refers only to Congress and imposes no restraint on the states. ${ }^{29}$ The use of this clause to lend weight to the argument that national uniformity of regulation is strongly implied by the Constitution and therefore state action is excluded, can be offset to some extent by pointing out that the reason for the inclusion of the clause was to prevent congressional regulations favorable to the powerful states. ${ }^{30}$

"The Migration or Importation of such Persons as any of the States now existing shall think proper to admit, shall not be prohibited by the Congress prior to the Year one thousand eight hundred and eight." ${ }_{3 x}$ From this it was argued that since the Constitution here expressly recognizes the power of the states to control foreign commerce in persons, it must contemplate the existence of the power over other articles as well. Chief Justice Marshall met this contention by construing the clause as excepting for a limited time the preexisting state power over this phase of foreign commerce from the otherwise complete delegation to Congress. ${ }^{32}$

It can be concluded that the ancillary commercial clauses of the Constitution do not, in themselves, decisively support either the exclusive or the concurrent theory. Perhaps the most significant fact is the grant of power to Congress to supervise and control state action in the matters of duties on imports, exports, and tonnage, of commercial compacts, and under the full faith and credit clause. These provisions together with the supremacy clause ${ }^{33}$ are more consistent with the concurrent theory, which is that Congress in its discretion can abrogate such state regulation of for-

27 U.S. Const., art. I, $\$$ 9, cl. 6.

${ }_{28}$ Passenger Cases, 7 How. (U.S.) 283, 4I4 (I849), per Wayne, J., in reference to a state law imposing a duty on the landing of immigrant passengers.

${ }_{29}$ Munn v. Illinois, 94 U.S. II3, I35 (I877); Morgan v. Louisiana, II8 U.S. 455, 467 (I886).

30 Warren, op. cit. supra note I5, at 586-8. $\quad 3^{3 x}$ U.S. Const., art. I, § 9, cl. I.

32 Gibbons v. Ogden, 9 Wheat. (U.S.) I, 206-7 (I824).

33 "This Constitution, and the Laws of the United States which shall be made in Pursuance thereof; and all Treaties made, or which shall be made, under the Authority of the United States, shall be the supreme Law of the Land; and the Judges in every State shall be bound thereby, any Thing in the Constitution or Laws of any State to the Contrary notwithstanding." U.S. Const., art. 6, cl. 2. 
eign and interstate commerce as are deemed contrary to the national interest. ${ }^{34}$

The wording of the general commerce clause- "The Congress shall have Power . . . . To regulate Commerce with foreign Nations, and among the several States, and with the Indian Tribes" 35 - of itself neither excludes nor reserves a concurrent, subordinate power in the states. But although not expressly made so, yet the grant of power to Congress may be exclusive in fact because of its very nature.

.... it has never been supposed, that this concurrent power of legislation extended to every possible case in which its exercise by the States has not been expressly prohibited. The confusion resulting from such a practice would be endless. .... Whenever the terms in which a power is granted to Congress, or the nature of the power, require that it should be exercised exclusively by Congress, the subject is as completely taken from the State Legislatures, as if they had been expressly forbidden to act on it. $3^{6}$

On the other hand it is not lightly to be assumed that the powers granted to Congress are exclusive by nature. Mr. Justice Story's statement on this point is the accepted doctrine.

The constitution containing a grant of powers in many instances similar to those already existing in the State governments, and some of these being of vital importance also to State authority and State legislation, it is not to be admitted that a mere grant of such powers in affirmative terms to Congress, does, per se, transfer an exclusive sovereignty on such subjects to the latter. On the contrary, a reasonable interpretation of that instrument necessarily leads to the conclusion, that the powers so granted are never exclusive of similar powers existing in the States, unless where the constitution has expressly in terms given an exclusive power to Congress, or the exertion of a like power is prohibited to the States, or there is a direct repugnancy or incompatibility in the exercise of it by the States. 37

The problem thus becomes narrowed down to a determination of whether the regulation of the conduct of foreign and interstate commerce by the states is necessarily repugnant to and inconsistent with the existence of a similar power in Congress whether the latter has been exercised

34 Madison, in The Federalist, no. 42, speaks of the "necessity of a superintending authority over the reciprocal trade of confederated states," language more suitable to describe a legislature than a court. For a similar conclusion see Burdick, The Law of the American Constitution 207 (1922).

35 U.S. Const., art. I, $\S 8$, cl. 3 .

${ }^{36}$ Sturges v. Crowninshield, 4 Wheat. (U.S.) I22, I93 (I8Ig), per Marshall, C. J.

${ }^{37}$ Houston v. Moore, 5 Wheat. (U.S.) I, 48-49 (I820), holding the militia power to be concurrent. The last sentence quoted is a paraphrase of Hamilton's statement in The Federalist, no. 32. 
in regard to such conduct or not. ${ }^{8}$ In this connection it is interesting to observe that several comparable grants of power to Congress have been held not to exclude state action. ${ }^{39}$

\section{CHANCELLOR KENT V. DANIEL WEBSTER}

The first litigation involving the negative implications of the commerce clause arose in connection with the famous New York steamboat monopoly. Livingston and Fulton, in consideration of the time and money they had expended in the successful development of steam as a motive power for boats, were granted an exclusive thirty-year franchise to operate steamboats on the waters of New York by the state legislature. In I8II they brought a bill to enjoin the operation of a competing steamboat which was carrying passengers between New York City and Albany. Chancellor Lansing dismissed the bill, but his decision was reversed and the injunction granted by the Court of Errors in Livingston v. Van Ingen.$^{4^{\circ}}$

The respondent's chief contention was that the New York statute granting the monopoly was void because in conflict with the exclusive powers of Congress to issue patents and regulate interstate and foreign commerce. The court was unanimous in denying this contention. The principal opinion was written by Chief Justice Kent, the most renowned jurist of that day. He began with a general consideration of the exclusiveness of congressional powers. The conclusion reached on this point he stated as follows:

Our safe rule of construction and of action is this, that if any given power was originally vested in this state, if it has not been exclusively ceded to congress, or if the exercise of it has not been prohibited to the states, we may then go on in the exercise of the power until it comes practically in collision with the actual exercise of some congres-

${ }^{38}$ In one of the earliest American legal textbooks, Judge St. George Tucker of Virginia stated, without giving any reason for his opinion, that the commercial power of Congress was exclusive. I Tucker's Blackstone's Commentaries, Appendix 180 (1803). This opinion is remarkable in view of the fact that Judge Tucker advocated strict construction of federal powers. $I d .$, Appendix $\mathbf{r}_{54}$.

${ }^{39}$ Taxing power, McCulloch v. Maryland, 4 Wheat. (U.S.) 3I6, 425 (I8Ig), per Marshall, C. J.; bankruptcy power, Sturges v. Crowninshield, 4 Wheat. (U.S.) I22, I95-7 (I8I9), per Marshall, C. J. (see excerpt set out in note 60 infra); Ogden v. Saunders, 12 Wheat. (U.S.) 213, 273-8I (I827), per Johnson, J. (good discussion); militia power, see note 37 supra. Contra: naturalization power, Chirac v. Chirac, 2 Wheat. (U.S.) 259, 269 (I8I7), per Marshall, C. J. (distinguished, Gibbons v. Ogden, 9 Wheat. (U.S.) I, 36 (I824), per Oakley, arguendo). For conflicting views as to the exclusiveness of the power of Congress to legislate for the recovery of fugitive slaves, see Prigg v. Pennsylvania, 16 Pet. (U.S.) 539, 622-5, 627-33, 635-6, 638-48, $652-8,660-3$ (1842), wherein several diverse theories are set forth.

$4^{\circ} 9$ Johns. (N.Y.) 507 (I812). 
sional power. When that happens to be the case, the state authority will so far be controlled, but it will still be good in all those respects in which it does not absolutely contravene the provision of the paramount law..$^{x}$

The distinguished Chief Justice then turned to the commerce clause and pointed out the impossibility of drawing a definite line between external commerce, asserted to be under the exclusive control of Congress, and internal commerce, admitted to be within the exclusive control of the states. The rule just stated, he believed, would eliminate much of the difficulty:

There can be no other safe or practicable rule of conduct. .... Whenever the case shall arise of an exercise of power by congress which shall be directly repugnant and destructive to the use and enjoyment of the appellants' grant, it would fall under the cognisance of the federal courts, and they would, of course, take care that the laws of the union are duly supported. .... But when there is no existing regulation which interferes with the grant, nor any pretence of a constitutional interdict, it would be most extraordinary for us to adjudge it void, on the mere contingency of a collision with some future exercise of congressional power. Such a doctrine is a monstrous heresy. It would go, in a great degree, to annihilate the legislative power of the states. $4^{2}$

May not a state forbid the circulation of bank notes of face value of less than one dollar, or lottery tickets, even though Congress at some future time might establish national banks with authority to issue fractional currency or a national lottery? The fact that New York may now, or in the future, abuse its power over its navigable waters is no reason to say that no such power exists. Congress can remedy the situation if it finds that commerce is being improperly burdened. This opinion stands as one of the ablest presentations of the concurrent power theory in the reports. ${ }^{43}$

As the efficiency of steamboats increased so did the resistance to the New York monopoly. In r8I9 Ogden, a licensee of Livingston and Fulton, filed a bill before the former Chief Justice, now Chancellor Kent praying that one Gibbons be enjoined from operating a steamboat in New York Bay. The defendant held a federal coasting license and was carrying passengers between Elizabethtown, New Jersey and New York City. The

$4 I d$. at 576 . This conclusion was fortified by a reference to the rule laid down in The Federalist, no. 32 (note 37 supra) which was said to be of great influence in persuading certain state conventions to adopt the Constitution. "Principles of construction solemnly sanctioned at that day, and flowing from such sources, are to be regarded by us, and by posterity, as coming in the language of truth, and with the force of authority." Livingston v. Van Ingen, 9 Johns. (N.Y.) 507,577 (1812).

4 Id. at 578 .

${ }^{43}$ Concurring opinions were delivered by Yates and Thompson, JJ. The latter was appointed to the United States Supreme Court in I823. He did not participate in the decision of Gibbons v. Ogden, but his dissent in Brown v. Maryland, I2 Wheat. (U.S.) 4I9, 449 (I827) and his separate opinion in City of New York v. Miln, II Pet. (U.S.) I02, I43 (I837) indicate that his views on the commerce clause remained unchanged. 
injunction was granted on the authority of the previous case, the chancellor holding that the license did not purport to authorize the licensee to navigate wherever he chose free of state regulations, but was merely evidence showing the American character of the vessel. ${ }^{44}$ The decree was affirmed by the Court of Errors. ${ }^{45}$

This time an appeal was taken to the United States Supreme Court. No effort was spared by the appellant. He retained as his counsel Daniel Webster, the leading advocate of the day, and William Wirt, the Attorney General of the United States. The task of overturning a decision supported not only by cogent reasoning but by the great prestige of Chancellor Kent and the New York Court of Errors was no light one even for such eminent counsel.

Webster's argument, which is ranked as one of his ablest, was, for those days, remarkably concise, occupying but thirty pages in the report. ${ }^{46} \mathrm{He}$ dwelt first on the friction which had sprung up between New York and the adjacent states as a result of the monopoly. Connecticut had enacted a statute forbidding a New York licensee from entering its waters, and New Jersey had provided that any licensee who interfered with a New Jersey citizen would be liable to the latter in treble damages. ${ }^{47}$ He then adverted to the causes leading to the adoption of the Constitution and asserted that the desire and intent to remove the possibility of hostile and provocative regulations of commerce was the paramount motive inducing its adoption. "Henceforth, the commerce of the States was to be an unit; and the system by which it was to exist and be governed, must necessarily be complete, entire, and uniform." ${ }^{88} \mathrm{He}$ argued that the power to regulate meant the power to give the rule and establish the system, a power incapable of being lodged in two bodies concurrently.49 It was not contended that the commercial power of Congress was exclusive in all respects, but only that it

44 Ogden v. Gibbons, 4 Johns. Ch. (N.Y.) I5० (I8Ig).

45 Gibbons v. Ogden, I7 Johns. (N.Y.) 488 (I820).

$4^{6}$ Gibbons v. Ogden, 9 Wheat. (U.S.) I, 3-33 (I824).

47 Id. at 8-9. Wirt in his peroration exhorted the Court to intervene else this friction would lead to civil war and the destruction of the Union. Id. at 183-6. It may well be that this argument had a great effect upon Marshall, a man who had devoted his life to building and preserving the Union. Regardless of theory, the Union was in danger and Congress had taken no steps to save it.

$4^{8} \mathrm{Id}$. at 14 . "That the United States form, for many, and for most important purposes, a single nation, has not yet been denied. In war, we are one people. In making peace, we are one people. In all commercial regulations, we are one and the same people." Cohens v. Virginia, 6 Wheat. (U.S.) $264,413-4$ (I82I), per Marshall, C. J. This statement is dictum, but it indicates that Marshall's preconception was in accord with Webster's argument.

49 Gibbons v. Ogden, 9 Wheat. (U.S.) I, I5-I6 (I824). 
was so as to "great commercial interests," such as monopolies of trade, navigation laws, embargoes, and general regulations of foreign commerce..$^{\circ}$ Webster found three flaws in Kent's concurrent power doctrine. It would jeopardize the harmonious functioning of our federal system if Congress were to undertake to overhaul and revise the legislation of the states as a regular duty.5x Secondly, the uncontested power of the states to regulate ferries, bridges, and turnpikes does not prove that the states should and do retain the commercial power, since those regulations are better classified as pertaining to the internal police power..$^{52}$ The third point is the most important:

.... The States may legislate, it is said, wherever Congress has not made a plenary exercise of its power. But who is to judge whether Congress has made this plenary exercise of power? Congress has acted on this power; it has done all that it deemed wise; and are the States now to do whatever Congress has left undone? Congress makes such rules as, in its judgment, the case requires; and those rules, whatever they are, constitute the system.

All useful regulation does not consist in restraint; and that which Congress sees fit to leave free, is a part of its regulation, as much as the rest. .33

This language is susceptible of two constructions. 54 If Webster meant that it would be improper for any body other than Congress to determine the meaning of congressional inaction, then it supports the contention that the power of Congress is immediately exclusive by virtue of the Constitution itself. On the other hand, it may be read as meaning that the considered silence of Congress is as effective as its legislation in superseding state regulation. The former construction seems more consistent with the rest of Webster's argument; the latter was destined to be revived many years later in the form of the "silence of Congress" doctrine.

\section{MARSHALL'S POTENT Dicta}

Chief Justice John Marshall was more than a great judge, he was primarily a great statesman. Ever working toward his life-long goal, the creation of a strong central government, he missed no opportunity to further that end. As a result, upon occasion he was guilty of departing from accepted standards of judicial technique. ${ }^{55}$ In Gibbons $v$. Ogden,,$^{56}$ for ex-

${ }^{50} \mathrm{Id}$. at 9-Io, I3-14, I5-I6. $\quad{ }_{51}^{\mathrm{I}} \mathrm{Id}$. at I6-I7. $\quad{ }^{52} \mathrm{Id}$. at I8-rg. $\quad{ }^{53} \mathrm{Id}$. at $\mathrm{r7}-\mathrm{I8}$.

$54 \mathrm{~A}$ third is possible, i.e., that Webster was referring to a situation where Congress had "occupied the field." See Bikle, The Silence of Congress, 4I Harv. L. Rev. 200, 202, note 6 (r927).

s5 For a criticism of Marbury v. Madison, I Cranch (U.S.) I37 (I803), from this standpoint, see McLaughlin, Marbury vs. Madison Again, I4 Am. Bar Ass'n J. 55 (I928).

${ }^{56} 9$ Wheat. (U.S.) I ( 1824$)$. 
ample, he violated what might be termed the judicial canon of economy by discussing and stating his opinion on issues not necessary to the decision. That case, under Marshall's analysis, could have been decided without touching upon the negative implications of the commerce clauseindeed, the result would have been the same had Kent's views on that point been adopted in toto..$^{57}$ All that Marshall actually decided was that Congress had constitutional authority to enact the coasting license statute, that that statute conferred on a licensee the privilege to navigate upon any coastal water in the United States, ${ }^{88}$ and that the New York steamboat monopoly was an interference with that privilege.

Regardless of their unnecessary character, the dicta of the Chief Justice in his opinion in this great and leading case have had a tremendous influence upon the development of the negative implications of the commerce clause. The exclusive theory was given strong support in two ways. First, Marshall undertook to refute the contrary arguments based on various other clauses in the Constitution, as already mentioned.59 But, more important, he stated the gist of Webster's argument and indicated that it was persuasive to his mind.

It has been contended by the counsel for the appellant, that, as the word "to regulate" implies in its nature, full power over the thing to be regulated, it excludes, necessarily, the action of all others that would perform the same operation on the same thing. That regulation is designed for the entire result, applying to those parts which remain as they were, as well as to those which are altered. It produces a uniform whole, which is as much disturbed and deranged by changing what the regulating power designs to leave untouched, as that on which it has operated.

There is great force in this argument, and the Court is not satisfied that it has been refuted.60

57 Kent himself pointed this out with evident satisfaction. I Kent, Commentaries on American Law 405-I3 (1826).

${ }^{88}$ This is the weak link in the chain. Justice Johnson in his concurring opinion declared that the sole purpose of the license was to prevent foreign vessels from evading the revenue laws. Gibbons v. Ogden, 9 Wheat. (U.S.) $x, 23 I-3$ ( 1824$)$. It seems probable that Marshall stretched a point here to avoid the necessity of definitely repudiating the concurrent theory.

59 See p. 562 supra.

${ }_{60}$ Gibbons v. Ogden, 9 Wheat. (U.S.) r, 209 (I824). Marshall himself had made a good answer to this argument some five years before. "It may be thought more convenient, that much of it should be regulated by State legislation, and Congress may purposely omit to provide for many cases to which their power extends. It does not appear to be a violent construction of the constitution, and it is certainly a convenient one, to consider the power of the States as existing over such cases as the laws of the Union may reach. But be this as it may, the powrer granted to Congress may be exercised or declined, as the wisdom of that body shall decide. If, in the opinion of Congress, uniform laws concerning bankruptcies ought not to be established, it does not follow that partial laws may not exist, or that State legislation of the subject must cease. It is not the mere existence of the power, but its exercise, which is incom- 
Guarded though this statement is, and despite the presence of an'express disclaimer to pasising on the argument, ${ }^{6 r}$ it apparently has served as the warrant for many statements that in Gibbons v. Ogden, the Supreme Court held that the commerce power of Congress is exclusive. ${ }^{62}$

Equally important was the modification of the exclusive theory which Marshall suggested. In speaking of the argument of respondent based on the inspection clause, he said:

That inspection laws may have a remote and considerable influence on commerce, will not be denied; but that a power to regulate commerce is the source from which the right to pass them is derived, cannot be admitted. .... They form a portion of that immense mass of legislation, which embraces every thing within the territory of a State, not surrendered to the general government; all which can be most advantageously exercised by the States themselves. Inspection laws, quarantine laws, health laws of every description, as well as laws for regulating the internal commerce of a State, and those which respect turnpike roads, ferries, \&c., are component parts of this mass. ${ }^{63}$

This is what might be termed the doctrine of classification of powers. The powers of a state are classified as regulation of interstate and foreign commerce, regulation of internal commerce, police regulation for the protection of health and safety, and the taxing ${ }^{64}$ power. To determine into which category to put a given state statute, the purpose of the legislature is looked to. ${ }^{65}$ Whether the exclusive theory is applicable to the first class

patible with the exercise of the same power by the States." Sturges v. Crowninshield, 4 Wheat. (U.S.) I22, I95-6 (18r9).

It should be noted, however, that this answer does not meet the irue exclusive power argument, i.e., that the Constitution itself demands that uniformity which results from exclusively federal regulation regardless of Congress' opinion as to the wisdom of allowing the states to regulate certain subjects, but it does weigh against the practical desirability of adopting that argument. As pointed out above (p. 568), Webster's argument is not free from ambiguity.

${ }^{6 r}$ Gibbons v. Ogden, 9 Wheat. (U.S.) I, 200 (I824). Justice Johnson's concurring opinion did squarely adopt Webster's argument as the sole basis of decision. Id. at 227, 23I-2.

${ }^{62}$ Rawle, View of the Constitution 81-4 (2d ed. 1829); 2 Story, Commentaries on the Constitution 5r3 (r833); North River Steam Boat Co. v. Livingston, 3 Cowen (N.Y.) 7rr, 743 (1825), per Savage, C. J.; City of New York v. Miln, II Pet. (U.S.) ro2, 158-9 (1837), per Story, J.; Groves v. Slaughter, I5 Pet. (U.S.) 449, 504-5 (I84I), per McLean, J.; id. at 5II, per Baldwin, J.

${ }^{63}$ Gibbons v, Ogden, 9 Wheat. (U.S.) I, 203 (r824).

${ }^{64} \mathrm{Id}$. at $20 \mathrm{I}-3$.

${ }^{65}$ Justice Johnson's opinion is explicit on this point. "It is no objection to the exercise of distinct, substantive powers, that, in their application, they bear upon the same subject. The same bale of goods, the same cask of provisions, or the same ship, that may be the subject of commercial regulation, may also be the vehicle of disease. And the health laws that require them to be stopped and ventilated, are no more intended as regulations on commerce, than the laws which permit their importation, are intended to innoculate the community with disease. Their different purposes mark the distinction between the powers brought into action; and while frankly exercised, they can produce no serious collision." Id. at 235 (italics added). 
or not, it is not as to the rest. They are concurrent powers which can be exercised freely in the absence of congressional action; but Marshall made it clear that they are subject to being superseded by such action. ${ }^{66}$

The announcement of this doctrine was in effect a victory for states' rights which offset in large part the support given to the exclusive theory by the other dictum. At the same time it opened the door to greater judicial power by introducing a highly elastic standard, the presumed legislative purpose, as a rule of decision. This was the first of many similar steps which were destined to vest the Supreme Court with almost uncontrolled superintendence of all state action affecting interstate and foreign commerce.

The classification of powers doctrine was directly applied in Willson $v$. Black Bird Creek Marsh Co. ${ }^{67}$ to uphold a state's power to dam a navigable tidal inlet for the purpose of draining a marsh and removing a menace to the health of the neighborhood. Marshall held that this obstruction of navigation was not in contravention of the commerce clause, and was not forbidden by the Coasting License Act.

Prior to this decision, however, Marshall had radically modified the classification doctrine. Broven v. Maryland $d^{68}$ involved a state license tax imposed on wholesalers of foreign merchandise. The defendant, an unlicensed importer, had been convicted of selling articles in the form in which they were imported. The Chief Justice held that this was a violation of that clause of the Constitution prohibiting a state from laying import duties without the consent of Congress. ${ }^{69}$ This construction of the clause was deemed necessary to prevent its ready evasion. The holding was limited to the facts, which circumstance led to the development of the "original package" doctrine as a test for fixing the dividing line between state and national control..$^{\circ}$

This case demonstrated the dangers involved in leaving the taxing power of the states free from all restraints except those specified in the Constitution. Therefore Marshall undertook to work out a broader limitation. As a second and distinct ground of decision he held that the tax in

${ }^{66} \mathrm{Id}$. at $2 \mathrm{rO}-\mathrm{Ir}$.

${ }^{67} 2$ Pet. (U.S.) 245 ( 1829 ). This decision gave trouble to succeeding judges who maintained that Marshall espoused the exclusive doctrine in its broader form. Passenger Cases, 7 How. (U.S.) 283, 397-8 (r849), per McLean, J.; Gilman v. Philadelphia, 3 Wall. (U.S.) $7 \mathrm{r} 3,743$ (I866), per Clifford, $\mathrm{J}$.

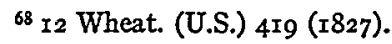

${ }^{69}$ U.S. Const., art. I, $\$$ Io, cl. 2, set out at p. 562 supra.

${ }^{70}$ For brief discussions of the development of this doctrine, see Sharp, op. cit. sicpra note*, at 604-Io; also, 2I Va. L. Rev. 433 (1935). 
question was repugnant to the federal tariff statutes. The payment of the tariff imposed by Congress, he said, confers on the importer not only the right to import, but the right to sell, without which the former right would be of little value. "Congress has a right, not only to authorize importation, but to authorize the importer to sell." ${ }^{7 x}$ And the tariff act will be so construed. Thus the actual holding does not support the exclusive theory any more than did that in Gibbons v. Ogden. But there are dicta in the case which, while far from clear, look in that direction..$^{72}$ At least they indicate that Marshall intended to revise his classification doctrine to remove the taxing power from the category of those regarded as concurrent under all circumstances. At the same time he reaffirmed the power of the states to exercise their police powers in the absence of inconsistent federal legislation. ${ }^{73}$

This second part of Marshall's opinion was a bold and novel departure from the accepted interpretation of the Constitution. To allay the fears of the states that their revenues might be curtailed by the activities of the proposed federal government, Hamilton had published the following statement in The Federalist:

The individual states should possess an independent and uncontrolable authority to raise their own revenues for the supply of their own wants. And making this concession, I affirm that (with the sole exception of duties on imports and exports) they would, under the plan of the convention, retain that authority in the most absolute and unqualified sense; and that an attempt on the part of the national government to abridge them in the exercise of it, would be a violent assumption of power, unwarranted by any article or clause of its constitution. ${ }^{74}$

A more emphatic denial of the applicability of the exclusive theory could hardly be phrased. Taney, counsel for Maryland in the Brown case, referred to it and pointed out that the people of the nation had relied on it

${ }^{7 x}$ Brown v. Maryland, I2 Wheat. (U.S.) 4I9, 447 (I827).

72 "The power claimed by the State is, in its nature, in conflict with that given to Congress." Id. at 447. "We admit this power [taxing] to be sacred; but cannot admit that it may be used so as to obstruct the free course of a power given to Congress. We cannot admit, that it may be used so as to obstruct or defeat the power to regulate commerce." Id. at 448 . "Or what should restrain a State from taxing any article passing through it from one State to another, for the purpose of traffic? .... These cases are all within the sovereign power of taxation, but would obviously derange the measures of Congress to regulate commerce, and affect materially the purpose for which that power was given." Id. at 449 .

73 Id. at $443-4$.

${ }^{74}$ The Federalist, no. 32. "A law abrogating or preventing the collection of a tax laid by the authority of a state, (unless upon imports and exports) would not be the supreme law of the land, but an usurpation of a power not granted by the constitution." Id., no. 33. Prima facie this looks inconsistent with the supremacy clause (note 33 supra), but Hamilton probably meant that it would never be "necessary" or "proper" for Congress to take such steps. 
when they adopted the Constitution. ${ }^{75}$ Nevertheless, Marshall, who had already established one implied limitation on the taxing power of the states, ${ }^{76}$ began the process of creating another and far more important one, a process not to be completed for nearly half a century. ${ }^{77}$

\section{CONFLICT AND COMPROMISE UNDER TANEY}

Not long after the ascension of Taney to the chief justiceship, it became apparent that his predecessor's attempt to settle the controversy as to the interpretation of the commerce clause had been far from successful. The diversity of opinion on this point among the members of the Supreme Court was exhibited in the case of City of New York v. Miln..$^{78}$ The majority of the Court upheld a statute requiring the masters of all vessels landing immigrants to file a report with the mayor giving information as to such persons. Justice Barbour, who wrote the prevailing opinion, based the decision on the ground that the statute was an exercise of the police power to protect the community against paupers and criminals, and was not in conflict with any federal statutes. He relied on Marshall's classification of powers doctrine, and denied the application of the exclusive theory as to the police power in strong terms. ${ }^{79}$ Justice Thompson, Kent's former colleague, delivered a concurring opinion in which he said that regardless of whether the state was to be regarded as exercising its police or its commercial power, the statute was valid in the absence of conflicting federal legislation..$^{80}$

Justice Story delivered a dissenting opinion in which he espoused the exclusive theory as qualified by the classification doctrine, ${ }^{8 x}$ but his con-

$7 s$ Brown v. Maryland, I2 Wheat. (U.S.) 419, 429-3I (I827).

${ }^{76} \mathrm{McCulloch} v$. Maryland, 4 Wheat. (U.S.) $3 \mathrm{I} 6$ (I8Ig), holding that federal governmental instrumentalities are exempt from state taxation, based on the supremacy clause and the lack of jurisdiction of the state, in the sense of power to create and regulate the Bank of the United States.

7 State Freight Tax Case, ${ }_{5}$ Wall. (U.S.) 232 ( 1873 ), p. 580 infra, was the first case squarely applying the exclusive theory to invalidate a state tax. In the interval Hamilton's interpretation was accepted doctrine. 2 Story, Commentaries on the Constitution 4ro-I2 (I833). "The States may unquestionably tax the subjects of commerce; and no necessary conflict with that complete control which is vested in Congress appears until the power is so exercised as to defeat or embarrass the congressional legislation. Where Congress has not acted at all upon the subject, the State taxation cannot be invalid on this ground." Cooley, Constitutional Limitations 486 (I868).

${ }^{88}$ II Pet. (U.S.) 102 (1837).

79 "All those powers which relate to merely municipal legislation, or what may, perhaps, more properly be called internal police, are not thus surrendered or restrained; and that, consequently, in relation to these, the authority of a state is complete, unqualified, and exclusive." Id. at I39.
8o Id. at 152 .
81 Id. at 156 . 
ception of the latter was quite different from that announced by Marshall and Johnson in Gibbons v. Ogden. "But how can it be truly said, that the act of New York is not a regulation of commerce? No one can well doubt, that if the same act had been passed by congress it would have been a regulation of commerce; and in that way, and in that way only, would it be a constitutional act of congress." ${ }_{2}$ Hence it must be classified as a regulation of foreign commerce when enacted by a state. This approach, of course, practically destroys the classification doctrine, and amounts to an adoption of the exclusive theory in its extreme form. Chief Justice Marshall, according to Story, had concurred in these views after the first hearing of the case. ${ }^{8_{3}}$

The conflict of views among the members of the Court increased with the years. In $\mathrm{r} 847$, the Court was unanimous in holding in the License Cases $^{84}$ that state statutes prohibiting the sale of liquor by unlicensed vendors could be validly applied to a retail vendor of foreign liquor and to an importer selling liquor imported from another state in the barrel in which it was imported. All of the judges agreed that the power of Congress could extend no further than the authorization of the importer to sell in the original packages, and that the police power of the states could, in the silence of Congress, be extended to prohibit sales of interstate imports even in the original packages. There was a sharp division, however, as to the reasoning on which the latter holding was based.

Justices McLean and Grier followed the modified exclusive theory as outlined in Gibbons v. Ogden, stating that although the states have no power to regulate external commerce for the purpose of bettering the conditions of its conduct, they can do so when the purpose is to protect the health, safety, or morals of their citizens..$^{85}$

Five members ${ }^{86}$ of the Court, led by Chief Justice Taney, based the decision on the concurrent theory of Chancellor Kent. They denied that the exclusive theory could be justified as a valid interpretation of the Constitution, ${ }^{87}$ and pointed out that no case had actually applied that theory as

${ }^{82}$ Id. at ${ }^{57}$.

$8_{3} I d$. at $x$ бr. Justice Story must be classed as the most wholehearted advocate of the exclusive theory in this period.

${ }_{84} 5$ How. (U.S.) 504 ( 1847 ). $\quad{ }^{8}$ Id. at $588-93,63 I-2$.

${ }^{86}$ Catron, Daniel, Woodbury, JJ., delivered separate opinions. Nelson, J., indicated his concurrence with Taney, C. J., and Catron, J. The remaining two justices who heard the case, Wayne and McKinley, probably agreed with McLean rather than Taney. See note 93 infra.

${ }_{87}^{8}$ License Cases, 5 How. (U.S.) 504, 578-80 (I847), per Taney, C. J.; id. at 605-8, per Catron, J. 
the basis of decision. ${ }^{88}$ Nor would they admit that the modified form of the exclusive theory was a satisfactory solution. They criticized the classification doctrine on the grounds that it did not square with governmental practice, and was both illogical and impracticable.

Chief Justice Taney vigorously attacked the propriety of judicial attempts to classify legislation according to the supposed motives of the legislature.

But what are the police powers of a State? They are nothing more or less than the powers of government inherent in every sovereignty to the extent of its dominions. And whether a State passes a quarantine law, or a law to punish offences, or to establish courts of justice, or requiring certain instruments to be recorded, or to regulate commerce within its own limits, in every case it exercises the same powers; that is to say, the power of sovereignty, the power to govern men and things within the limits of its dominion. It is by virtue of this power that it legislates; and its authority to make regulations of commerce is as absolute as its power to pass health laws, except in so far as it has been restricted by the constitution of the United States. .... .

Upon this question the object and motive of the State are of no importance, and cannot influence the decision. It is a question of power. ${ }^{89}$

Furthermore, continued the Chief Justice, regardless of the obvious difficulty of determining the legislative motive in many cases, ${ }^{90}$ the classification variation of the exclusive theory limits the states too much on one hand and not enough on the other. For half a century and more Congress had permitted the regulation of pilotage to be handled locally, yet this was a "commercial" regulation of foreign commerce. Would it now be urged that all state pilotage laws are and always have been unconstitutional? ${ }^{9 x}$ Again, would it be admitted that the states may, as a health measure, cut off all commerce in an article by forbidding its sale and use? ${ }^{92}$

The Passenger Cases, ${ }^{93}$ decided two years later, were of little importance

${ }^{88} I d$. at $58 \mathrm{I}-4$, per Taney, C. J.; id. at 602-5, per Catron, J.

$\overline{8} 9 \bar{I} \vec{d}$. at $5 \hat{8}_{3}$.

${ }^{90}$ Justice Thompson pointed out this difficulty in City of New York v. Miln, II Pet. (U.S.) IO2, I52-3 (I837).

9x License Cases, 5 How. (U.S.) 504, 580-I (1847), per Taney, C. J.; id. at 606-7, per Catron, J.

${ }_{92}$ Id. at $600-\mathrm{I}$, per Catron, J. This question was to trouble the Court many years later. See p. $5^{84}$ infra.

${ }^{93} 7$ How. (U.S.) 283 ( 1849 ), holding invalid statutes imposing fees on masters of vessels for each immigrant landed. Two justices, McLean and Wayne, based the decision on both the exclusive theory and repugnance to federal statutes and treaties. Catron, McKinley, and Grier, JJ., concurred, relying on the latter ground. Taney, C. J., Daniel, Nelson, and Woodbury, JJ., dissented. The Chief Justice contended inter alia that the concurrent theory had been adopted in the License Cases, and that the commerce clause imposed no limitation on the taxing power of the states. Id. at $470-\mathrm{r}, 479-82$. 
in the development of the negative implications of the commerce clause, but the truculent pertinacity with which the Justices clung to their diverse theories made it obvious that a new compromise was necessary. Marshall's attempt to win over the adherents of the concurrent theory had failed.

The new compromise theory was not long in coming. It was announced, ${ }^{94}$ appropriately, by a new member of the Court, Justice Curtis, in Cooley v. Board of Warden ${ }^{95}$ in $185^{2}$. The case involved the validity of a state law requiring vessels to pay half of the pilotage fees whether they used a local pilot or not. This statute was held to be a regulation of commerce rather than of police. ${ }^{96}$ Nevertheless it was upheld on the ground that the power of Congress over such matters was not exclusive. The compromise doctrine was stated as follows:

The diversities of opinion, therefore, which have existed on this subject, have arisen from the different views taken of the nature of this power. . . . . Now the power to regulate commerce, embraces a vast field, containing not only many, but exceedingly various subjects, quite unlike in their nature; some imperatively demanding a single uniform rule, operating equally on the commerce of the United States in every port; and some, like the subject now in question, as imperatively demanding that diversity, which alone can meet the local necessities of navigation.

Either absolutely to affirm, or deny that the nature of this power requires exclusive legislation by Congress, is to lose sight of the nature of the subjects of this power, and to assert concerning all of them, what is really applicable but to a part. Whatever subjects of this power are in their nature national, or admit only of one uniform system, or plan of regulation, may justly be said to be of such a nature as to require exchusive legislation by Congress. That this cannot be affirmed of laws for the regulation of pilots and pilotage is plain. 97

Justice Curtis made it clear that his decision was not based on any delegation of power to the states by Congress. A federal statute of $I 789$ provided that all pilots should continue to be regulated by existing state laws and those thereafter to be enacted, until further legislation by Congress. The state statute in question was enacted in I803. Justice Curtis stated that its validity could not be made to depend on the Act of $I 789$. "If the

94 Justice Woodbury had already suggested the possibility of reconciling the exclusive and concurrent theories by an approach somewhat similar to that adopted by his successor. $\mathrm{Li}$ cense Cases, 5 How. (U.S.) 504, 624-5 (r847); Passenger Cases, 7 How. (U.S.) 283, 559-6r (I849).

95 I 2 How. (U.S.) 299 (1852).

${ }^{95} \mathrm{Id}$. at 317 . The opinion in this case did not purport to abandon the classification doctrine. Instead it further curtailed the field in which the exclusive theory is operative. See Fanning v. Gregoire, I6 How. (U.S.) 524 ( 1854 ), holding the grant of an exclusive franchise to operate an interstate ferry to be within the "police" power of a state, hence valid in the silence of Congress.

97 Cooley v. Board of Wardens, I2 How. (U.S.) 299, 319 (I852) (italics added). Justice Daniel, concurring specially, argued that Congress had no power at all as to matters demanding diversity of treatment. Id. at $325-6$. 
states were divested of the power to legislate on this subject by the grant of the commercial power to Congress, it is plain this act could not confer upon them power thus to legislate."98 The only effect of the federal statute was to indicate Congress' belief that the subject of pilotage was not one demanding uniformity of regulation. ${ }^{99}$ In the instant case this coincided with the opinion of the Court. In cases where Congress has expressed no opinion the Court will determine if the subject is of national interest or one which demands uniformity according to its understanding of the needs of commerce. Thus another opportunity for the use of judicial discretion in imposing limitations on the power of the states was created-which may explain in part the continued favor with which the Supreme Court has viewed the doctrine of the Cooley case.

\section{THE TRIUMPH OF NATIONALISM}

On the whole it can be said that the "concurrent" interpretation of the commerce clause was predominant during the term of Chief Justice Taney. The decade following the Civil War saw the pendulum swing sharply the other way. The doctrine of state sovereignty, one of the bases of the concurrent theory, was gone and with it the idea that the Constitution was to be construed as a contract between the states and the federal government. The personnel of the Supreme Court was almost entirely changed.00 Commerce was becoming more and more national in scope and character as a result of the rapid expansion of railroad and telegraph systems. These three reasons are ample to explain the change in judicial attitude toward the commerce clause and state powers.

The first warning of the impending curtailment of state powers came in Steamship Co. v. Portwardens ${ }^{\mathrm{ror}}$ involving a Louisiana statute which authorized the portwardens of New Orleans to collect a fee of five dollars from every vessel entering the port whether receiving any services or not. The Supreme Court held the statute unconstitutional in a brief and dogmatic opinion by Chief Justice Chase. "That the act of the legislature of Louisiana is a regulation of commerce can hardly be doubted. It imposes a tax upon every ship entering the port of New Orleans . . . . and works the very mischief against which the Constitution intended to protect com-

${ }^{8} \mathrm{Id}$. at $3 \mathrm{r} 8$.

99 Justices McLean and Wayne, dissenting, construed the Act of 1789 as reflecting a belief by Congress that it was necessary to adopt the state laws because they had been automatically abrogated by the adoption of the Constitution. Id. at 322-3.

${ }^{100}$ In $I 867$ only three members of the Court of 5860 remained; in 1873 , only one. President Lincoln made five appointments to the Court.

sor 6 Wall. (U.S.) 3 I (I867). 
merce among the States." ${ }^{\prime 02}$ No authority for this statement was cited. The exclusive theory was applied as a matter of course and the Cooley case was distinguished by pointing out that here Congress had not sanctioned the state statute and there was no element of contract as there was in the case of the half pilotage fee. As a second ground of decision, Chief Justice Chase held the tax void as a duty on tonnage, construed to include any duty levied on a ship as such. The presence of this narrow alternative ground and the lack of reasoning and discussion of precedent make the case of little weight as an authority.

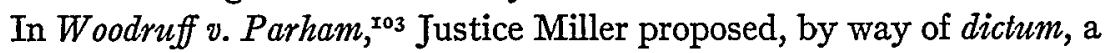
new limitation on the power of the states. This case involved the validity of a municipal ordinance imposing a tax on auctioneers measured by the proceeds of their sales, as applied to an auctioneer selling in their original packages goods imported from other states. Justice Miller upheld the tax in spite of the contention that the case was governed by Brown v. Maryland. The word "imports," said he, as used in the Constitution refers only to goods introduced from foreign countries. Marshall's further suggestion that the commerce clause impliedly prohibits state taxation of original package sales of interstate imports ${ }^{\mathrm{T} 4}$ was limited to the facts of the Brown case, i.e., to a discriminatory tax. The opinion concluded thus:

But, we may be asked, is there no limit to the power of the States to tax the produce of their sister States brought within their borders? And can they so tax them as to drive them out or altogether prevent their introduction or their transit over their territory?

The case before us is a simple tax on sales of merchandise, imposed alike upon all sales made in Mobile, whether the sales be made by a citizen of Alabama or of another State, and whether the goods sold are the produce of that State or some other. There is no attempt to discriminate injuriously against the products of other States or the rights of their citizens, and the case is not, therefore, an attempt to fetter commerce among the States, or to deprive the citizens of other States of any privilege or immunity possessed by citizens of Alabama. But a law having such operation would, in our opinion, be an infringement of the provisions of the Constitution which relate to those subjects, and therefore void. There is also, in addition to the restraints which those

${ }^{102}$ Id, at 33 . 2038 Wall. (U.S.) I23 (1869).

ro4 "We suppose the principles laid down in this case, to apply equally to importations from a sister State. We do not mean to give any'opinion on a tax discriminating between foreign and domestic articles." Brown v. Maryland, I2 Wheat. (U.S.) 4I9, 449 (I827). A possible explanation of why Marshall did not base the decision in Brown v. Maryland on the discriminatory nature of the tax is that he held an absolute view of governmental power. "Questions of power do not depend on the degree to which it may be exercised. If it may be exercised at all, it must be exercised at the will of those in whose hands it is placed." Id. at 439. To his mind to say that the state could tax an importing dealer uniformly with other merchants would necessarily imply that an unequal and prohibitory tax would also be valid. 
provisions impose by their own force on the States, the unquestioned power of Congress, under the authority to regulate commerce among the States, to interpose, by the exercise of this power, in such a manner as to prevent the States from any oppressive interference with the free interchange of commodities by the citizens of one State with those of another. ${ }^{\text {.05 }}$

Justice Miller amplified and varied his reasoning, again by way of dictum, in Hinson v. Lott, ${ }^{\mathrm{x} 6}$ decided on the same day. A tax discriminating against the products of other states would, he said, be void as a regulation of commerce in respect of a matter of national interest under the doctrine of the Cooley case. The rule to be deduced from the opinion seems to be that a tax will be regarded as a forbidden "regulation" if its effect is to "seriously affect the interchange of commodities," ${ }_{x 07}$ and it is so intended by the legislature. ${ }^{\text {xo8 }}$

The doctrine announced by Justice Miller in these two cases found little support in the authorities. ${ }^{\text {xog }}$ It can be rationalized in two ways. First, it could be urged that the primary purpose of the constitutional provisions in regard to commerce is to prevent discriminatory action by states resulting in a burden on commerce and causing irritation among the states. It would be folly to circumscribe the action of the states in other respects and leave them free to produce the same evils by means of internal taxation. Hence the prohibition of discriminatory taxation can be regarded as a "resulting" limitation on state power. ${ }^{\text {Ix }}$ The apparent reliance on the privileges and immunities clause of Article IV as an analogy in Woodruff v. Parham is evidence that Miller did follow this line of reasoning. But, as

${ }^{05}$ Woodruff v. Parham, 8 Wall. (U.S.) I23, I40 (I869).

${ }^{106} 8$ Wall. (U.S.) 148 (r869), holding valid a state tax of $5 \circ$ per gallon on the sale of imported liquor where there was a similar tax levied upon the distillation of liquor in the state.

${ }^{207} \mathrm{Id}$. at I5I.

${ }^{\text {ro8 }}$ Speaking of the tax described in note 106 supra, Miller, J., said, "We do not see in it an attempt to regulate commerce, but an appropriate and legitimate exercise of the taxing power

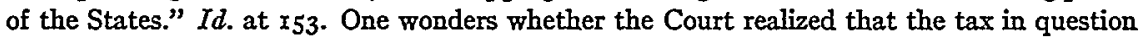
was in fact discriminatory. Thus if each state were to adopt such a system of taxation it is obvious that, all other things being equal, imported liquor would cost the consumer $5 \circ \mathrm{C}$ more per gallon than the domestic product.

${ }^{209}$ In addition to the Brown and Cooley cases, neither of which supported his position, Miller cited Almy v. California, 24 How. (U.S.) I69 (I86I), holding a tax on bills of lading invalid as a duty on exports, and Crandall v. Nevada, 6 Wall. (U.S.) 35 (r868), holding invalid a tax on passengers leaving the state. In the latter case only Chase, C. J., and Clifford, J., put the decision on the commerce clause. Miller himself wrote the majority opinion which refused to find the tax a regulation of commerce in a matter of national concern within the doctrine of the Cooley case.

"ro For an analogous proposition, i.e., that Congress possesses "resulting" powers, see Legal Tender Cases, I2 Wall. (U.S.) 457, 534-7 (1872), per Strong, J. 
noted above, ${ }^{\text {Irr }}$ the presence of that clause in the Constitution raises an inference that no corresponding protection to goods of extrastate origin was intended. Moreover, there is the difficulty of getting around the proposition that the Constitution contains no implied limitations on the taxing power of the states.

The second possible rationalization avoids these objections to a large extent. It starts with the doctrine of the Cooley case that the power of Congress is exclusive as to the regulation of commercial subjects of national concern, among which is the interstate movement of goods. No state can directly hamper such movement by commercial regulations, that is, where the purpose is to aid domestic commercial interests. It follows that although a state can impose bona fide taxes on the subjects and conduct of commerce, it cannot use its taxing power as a colorable device to further commercial ends. It cannot do indirectly what it cannot do directly. The discriminatory nature of the tax betrays the real legislative motive. Upon this analysis the doctrine of these cases can be considered as a modification of the classification doctrine announced in Gibbons $v$. Ogden. .ra $^{\mathrm{Ir}}$

A far more revolutionary doctrine was not only announced but applied in the State Freight Tax Case. ${ }^{113}$ A Pennsylvania statute laid a tax of from two to five cents per ton on all freight transported by a common carrier by rail or water any distance within the state. A railroad company resisted payment of the tax on coal shipped from within the state to a point outside, and was sustained in its contention by the United States Supreme Court. Justice Strong delivered the majority opinion. ${ }^{\mathrm{II}} 4$

The payment of that tax is a condition, upon which is made dependent the prosecution of this branch of commerce. And as there is no limit to the rate of taxation she may impose, if she can tax at all, it is obvious the condition may be made so onerous that an interchange of commodities with other States would be rendered impossible. ... . Such an imposition, whether large or small, is a restraint of the privilege or right to have the subjects of commerce pass freely from one State to another without being obstructed by the intervention of State lines. It would hardly be maintained, we think, that had the State established custom-houses on her borders . . . . and demanded at these houses a duty for allowing merchandise to enter or leave the State . . . . such an imposition would not have been a regulation of commerce with her sister States. Yet it

Irr See p. 56x supra.

xn The doctrine of the Woodruff case has been applied to invalidate state police regulations as well as taxes. Minnesota v. Barber, $\mathrm{I}_{3} 6$ U.S. $3{ }^{13}$ (1890); Voight v. Wright, I4I U.S. 62 (I8gI).

${ }^{113}{ }_{5} 5$ Wall. (U.S.) 232 (1873).

II Swayne and Davis, JJ., construed the tax as a valid tax on the business of the carriers. Id. at 282 . 
is difficult to see any substantial difference between the supposed case and the one we have in hand. . . . . Nor can it make any difference that the legislative purpose was to raise money for the support of the State government, and not to regulate transportation. It is not the purpose of the law, but its effect, which we are now considering. Nor is it at all material that the tax is levied upon all freight, as well that which is wholly internal as that embarked in interstate trade. 215

And since the subject demands uniformity of regulation under the doctrine of the Cooley case, the "regulation" here is unconstitutional. .r6 $^{10}$

This decision is based on the exclusive theory as modified by the Cooley case. The first difficulty came in squaring it with Marshall's classification doctrine. ${ }^{\mathrm{Ix} 7}$ Justice Strong eliminated the necessity of this by blandly throwing the latter overboard. The second and greater difficulty came in reconciling the decision with the orthodox view that the Constitution contains no implied limitations on the taxing power of the states. ${ }^{\text {1r8 }}$ Two lines of reasoning were resorted to. Payment of the tax is a condition imposed upon persons engaging in interstate commerce; the imposition of conditions is regulation; the power to regulate interstate and foreign commerce was completely surrendered to Congress; therefore the state has no power to levy the tax. Not only does this beg the question by a process of defining terms, but it proves too much, i.e., that a state property tax on railroad rights-of-way would be invalid. Again, state customs duties on interstate exports and imports are forbidden, therefore interstate commerce is to be free of state-imposed burdens: the tax in issue is a burden, therefore it is forbidden. Non sequitur, of course. It does not follow that because the Constitution can be reasonably construed to prohibit the states from imposing certain restraints on interstate commerce, such commerce has a constitutional immunity from all state-imposed restraints. No attempt was made to explain away Hamilton's statements in The Federalist, ${ }^{\mathrm{Ir} 9}$ and repeated by Story in his Commentaries, ${ }^{\mathbf{1 2 0}}$ or the inference which may be drawn from the presence of certain specific limitations on the taxing power of the states in the Constitution. ${ }^{\text {I2I }}$ It is not exaggerating to say that the decision in the State Freight Tax Case, one of the most important ever made under the commerce clause, was reached in disregard of authority and was based on faulty logic and dubious policy.

$$
\text { IIs } I d \text {. at } 276-7 . \quad \quad{ }^{116} I d \text {. at } 279-80 \text {. }
$$

${ }^{127}$ See p. 570 supra. It will be recalled that Marshall himself had later questioned the position that the exclusive theory could never be applied to state taxation. See p. 572 supra.

${ }^{118}$ See p. 572 supra. It is surprising to find Justice Clifford stating a few years later that it is a "settled rule of construction" that "the commercial clause of the Constitution neither confers, regulates, nor prohibits taxation." Transportation Co. v. Wheeling, 99 U.S. 273,285 (I878).

${ }^{\text {Ixg }}$ See note 74 supra.

${ }^{220}$ See note 77 supra.

${ }^{22 x}$ See p. $5^{62}$ supra. 
Justice Miller's rule might be summarized thus: state taxes which (intentionally) burden interstate commerce (more than intrastate commerce) are forbidden regulations of interstate commerce. Justice Strong's is the same, omitting the words in parentheses. But it immediately became apparent that this rule was too broad. On the same day that it was announced, the Court in the case of State Tax on Railway Gross Receipts ${ }^{122}$ upheld a tax of that type. Justice Strong distinguished the first case by saying, "It is not everything that affects commerce that amounts to a regulation of it, within the meaning of the Constitution." And, he said, the Constitution should not be construed to destroy the revenue sources of the states. ${ }^{123}$ This seems to leave the matter entirely within the discretion of the Court.

A few years later, in his opinion in Sherlock v. Alling,, ${ }^{, 24}$ Justice Field devised a method of glossing over awkward problems of distinguishing cases such as were presented in State Tax on Railway Gross Receipts. ${ }^{\mathrm{I25}}$ The method was to draw the line between "direct" burdens on and regulations of interstate commerce and those "indirect" in effect. ${ }^{\mathrm{I} 26}$ This formula amounts to a substitute for that laid down in the Cooley case. In vagueness of meaning, the "direct burden" doctrine exceeds all the rest; it leaves the Court practically free to decide each case as it wishes. ${ }^{127}$ The Supreme Court has appreciated its advantages. ${ }^{\mathrm{I28}}$ At any rate, Justice Field's doctrine has been frequently used, especially in taxation cases.

Another blow at the classification doctrine was struck in Hendersoni $v$. Mayor of New York, ${ }^{129}$ holding invalid a statute requiring the payment of a fee by the master of the vessel for each immigrant landed. Justice Miller said that it made no difference whether or not this were regarded as an

${ }^{222}{ }_{15}$ Wall. (U.S.) 284 (I873).

${ }^{223} I d$. at 293. Justice Miller delivered a vigorous dissenting opinion, in which Field and Hunt, JJ., concurred, urging that the Constitution be construed to prevent the recurrence in any form of those burdens and restrictions on commerce which were its primary cause. Id. at $297-9$.

${ }^{224} 93$ U.S. 99 ( 1876$)$, holding an interstate carrier by water liable under a state wrongful death act.

${ }^{225}$ I 5 Wall. (U.S.) 284 ( 1873$)$.

${ }^{126} 93$ U.S. 99,103 ( 1876 ).

${ }^{227}$ "In this case the traditional test of the limit of state action by inquiring whether the interference with commerce is direct or indirect seems to me too mechanical, too uncertain in its application, and too remote from actualities, to be of value. In thus making use of the expressions, 'direct' and 'indirect interference' with commerce, we are doing little more than using labels to describe a result rather than any trustworthy formula by which it is reached." Di Santo v. Pennsylvania, 273 U.S. 34, 44 (1927), per Stone, J., dissenting.

${ }^{22}$ See p. $5^{89}$ infra. $\quad{ }_{229}^{92}$ U.S. 259 (1876). 
exercise of the police power. It amounted to a regulation of foreign commerce as to a subject demanding uniformity and hence was void. ${ }^{\text {x3o }}$

Almost complete victory for the exclusive theory was attained in the group of cases just discussed. The police and taxing power exceptions from its scope had been repudiated, and the field of concurrent power as blocked out in the Cooley case had been narrowed by a broad interpretation of the "uniformity" test of that case. Henceforth, the Court was to be chiefly concerned with the application, rather than the selection, of doctrines. There was soon to occur, however, one more interesting and important development.

\section{THE SILENCE OF CONGRESS AND ITS VOICE}

When called upon to translate the doctrine of Woodruff v. Parham into a decision in Welton v. Missouri, ${ }^{\text {xix }}$ Justice Field undertook to provide a new rationalization for the doctrine of the former case.

It is sufficient to hold now that the commercial power [of Congress] continues until the commodity has ceased to be the subject of discriminating legislation by reason of its foreign character. That power protects it, even after it has entered the State, from any burden imposed by reason of its foreign origin. . . . .

The fact that Congress has not seen fit to prescribe any specific rules to govern inter-State commerce does not affect the question. Its inaction on this subject, when considered with reference to its legislation with respect to foreign commerce, is equivalent to a declaration that inter-State commerce shall be free and untrammelled. As the main object of that commerce is the sale and exchange of commodities, the policy thus established would be defeated by discriminating legislation like that of Missouri. ${ }^{32}$

The meaning of these passages is obscure. A statement made by Justice Field a few years later leads one to conclude that he did not intend to announce an independent doctrine, but rather to bolster up Justice Miller's argument in Woodruff v. Parham ${ }^{\mathrm{r} 33}$ by suggesting an additional reason why the result reached in Welton v. Missouri was sound, i.e., because it coincided with the wishes of Congress. The statement referred to was made by way of dictum in County of Mobile v. Kimball: $:^{\mathrm{r} 34}$

Some of them [subjects of commercial regulation] are national in their character, and admit and require uniformity of regulation, affecting alike all the States. .... Here there can of necessity be only one system or plan of regulations, and that Con-

${ }^{230} I d$. at $27 \mathrm{r}-3$. Miller, J., adverted to the difficulty of applying the classification doctrine, and pointed out that Congress had power to enact a similar statute under its commercial power, the same point made by Story, J. (see p. 574 supra).

${ }^{231} 9$ I U.S. 275 ( 1876 ), holding invalid a license tax on peddlers of goods of extrastate origin. ${ }_{232} I d$. at 282 .

ז33 8 Wall. (U.S.) I23 (1869). See p. 578 sutpra. 134 I02 U.S. 69I (188r). 
gress alone can prescribe. Its non-action in such cases with respect to any particular commodity or mode of transportation is a declaration of its purpose that the commerce in that commodity or by that means of transportation shall be free.,35

On the other hand in respect of matters of local concern the silence of Congress, said the learned Justice, indicates an intent to permit regulation by the states..$^{x}{ }^{36}$

All of which adds nothing whatever to the doctrine of the Cooley case insofar as the results of its application are concerned, since presumably the Court is to continue to draw the line between matters of national and those of local concern. Justice Field's effort might be interpreted as an attempt to conceal the blunt reality of judicial control behind an apparent deference to the "will" of Congress-conveniently discovered to coincide with that of the Court. Be that as it may, it is doubtful if the learned Justice foresaw the end to which his words were to lead.

In Boreman v. Chicago \& R. Co., ${ }^{\mathrm{x} 7}$ the Supreme Court held that a "dry" state had no power to prohibit the interstate importation of liquor for use therein. The majority opinion, delivered by Justice Matthews, consisted largely of a rather labored attempt to show that the statute must be classified as a regulation of interstate commerce rather than of police. ${ }^{138}$ He relied chiefly on the point made by Justice Catron in the License Cases, $^{\mathrm{I} 39}$ that the federal commercial power would be really subordinate if the states in the exercise of their police powers could outlaw traffic in certain commodities. Hence it was believed necessary to limit the "police" power branch of the classification doctrine, insofar as prohibition of importation was concerned, to unmerchantable articles such as diseased animals and decayed food..$^{10}$ Such a construction of the classification doctrine goes far toward limiting it out of existence. In a strong dissenting opinion Justice Harlan maintained that the statute fell within the police power of the state and that that power could be freely exercised in the absence of conflicting federal legislation. . $^{\mathrm{II}}$

The most interesting feature of the case was the twist given by Justice

${ }^{135} I d$. at 697. $\quad{ }^{236} I d$. at 698-9. $\quad{ }^{237}$ I25 U.S. 465 (I888).

${ }^{238}$ "It is essentially a regulation of commerce among the States within any definition heretr' re given to that term, or which can be given; and although its motive and purpose are to perfect the policy of the State of Iowa in protecting its citizens against the evils of intemperance, it is none the less on that account a regulation of commerce." Id. at 493 . Reliance was also put on the extrastate effect of the statute on shippers and carriers. Id. at 486, 498-9.

${ }^{139}$ See p. 575 supra.

x40 Bowman v. Railway Co., I25 U.S. 465,489 (x888).

14 Id. at 509. Waite, C. J., and Gray, J., concurred in the dissent. 
Matthews to Justice Field's "silence of Congress" meaningless verbal formula of the County of Mobile case was turned about and transformed into a proposition of great potential effect. "It [a state] cannot, without the consent of Congress, express or implied, regulate commerce between its people and those of the other States of the Union in order to effect its end, however desirable such a regulation might be." ${ }^{244}$ This seems to be a declaration that Congress can permit the states to regulate interstate commerce in respect of matters which the Supreme Court would classify as those of national concern under the doctrine of the Cooley case.

Why, in the midst of the process of extending the limitations on state power under both the Fourteenth Amendment and the commerce clause, did the Court make this gesture of abdicating its position to Congress? It is not improbable that the justices were unsure of their position and wished to prepare an avenue of graceful retreat by shifting the ultimate responsibility to Congress. The extension of the negative implications of the commerce clause had been tremendous in the two decades since the Civil War. ${ }^{145}$ Perhaps the Court was afraid that it had carried things too fast and too far, particularly in regard to the practical abandonment of the classification doctrine. Maybe the members of the majority in the Bowman case, observing the apparent virility of the prohibition movement, doubted whether their own rather unsympathetic attitude toward

${ }^{{ }_{42}}$ Borrowed from Bikle, The Silence of Congress, 4I Harv. L. Rev. 200 (I927).

${ }^{243}$ It is significant that Justice Field did not concur in this step, but filed a separate concurring opinion. Bowman v. Railway Co., I25 U.S. 465, 500 (I888).

214 Id. at 493 (italics added). Again: "If not in contravention of any positive legislation by Congress, it is nevertheless a breach and interruption of that liberty of trade which Congress ordains as the national policy, by willing that it shall be free from restrictive regulations." $I d$. at 498 .

I45 The State Freight Tax Case, I5 Wall. (U.S.) 232 ( 1873 ), was the first decision based squarely and solely on the exclusive theory. It was followed by Welton v. Missouri, gI U.S. 275 (1876) (tax discriminating against peddlers of imported goods); Henderson v. Mayor of New York, 92 U.S. 259 ( 1876 ) (tax on landing of immigrants); Railway Co. v. Husen, 95 U.S. 465 (1878) (import embargo on Texan cattle); Hall v. De Cuir, 95 U.S. 485 (I878) (statute requiring river steamboats to furnish equal accommodations for white and black passengers); Western Union Telegraph Co. v. Texas, 105 U.S. 460 (I882) (tax on all telegraph messages); Gloucester Ferry Co. v. Pennsylvania, II4 U.S. I96 (I885) (tax on entire capital stock of foreign corporation engaged solely in interstate commerce); Wabash, etc., R. Co. v. Illinois, II8 U.S. 557 (I886) (regulation of freight rates on interstate shipments); Robbins v. Taxing District, 120 U.S. 502 (1887) (non-discriminatory tax on drummers); Philadelphia, etc., S. S. Co. v. Pennsylvania, I22 U.S. 326 (1887) (franchise tax on domestic corporation measured by gross receipts). In all of these cases the state legislation was held unconstitutional because of the exclusive character of the power of Congress over the particular subject-matter. 
that movement ${ }^{\mathrm{x} 46}$ reflected the dominant public opinion of the country. Did national public policy demand that the interstate liquor traffic be immune from state interference? Perhaps the justices were coming to believe that a legislature was better equipped to answer such questions than was a court of law, a belief which may have been shared by the framers of the Constitution, judging by the language of that document.

Two years later the reasoning of the Bowman case was carried to its logical conclusion in Leisy v. Hardin, ${ }^{\mathrm{I} 47}$ holding that a state could not forbid "original package" sales of liquor imported from another state, and overruling the License Cases insofar as they were inconsistent with the result now reached..$^{\mathrm{I}} 8$ Although his opinion is marked by confusion of thought, Chief Justice Fuller made it clear that Congress could, in effect, overrule the decision if it wished.

And while by virtue of its jurisdiction over persons and property within its limits, a State may provide for the security of the lives, limbs, health and comfort of persons and the protection of property so situated, yet a subject matter which has been confided exclusively to Congress by the Constitution is not within the jurisdiction of the police power of the State, unless placed there by congressional action..49

Congress lost no time in accepting the invitation to speak. The Wilson $\mathrm{Act}^{\mathrm{5} 50}$ of $\mathrm{I} 890$ purported to subject imported liquor to the "police power" of a state upon its arrival and delivery for use or sale therein regardless of the form of the package. No better illustration of the artificiality of using an inference drawn from the silence of Congress as a basis of decision need be sought.

In the case of In re Rahrer ${ }^{\mathrm{rs}}$ the Supreme Court bowed to the wishes of Congress and upheld a state statute, enacted prior to the Wilson Act, forbidding the sale of liquor by its importer in the original package. The ra-

${ }^{{ }^{4} 6} \mathrm{Cf}$. Plumley v. Massachusetts, ${ }_{55}$ U.S. $46 \mathrm{I}$ (1894), upholding state statute forbidding sale in original packages of imported oleomargarine colored to resemble butter. Presumably the Court believed the evil here to be greater than in the Bowman Case.

${ }^{147}$ I35 U.S. 100 (I890). Gray, Harlan, and Brewer, JJ., dissented.

${ }_{348}$ The dissenting opinion points out that the silence of Congress during the forty years that the License Cases were regarded as the law of the land is strong evidence of approval of the results there reached, rather than, as the majority would have it, a mute protest against those decisions. $I d$. at 160 .

x49 Id. at ro8 (italics added). It would seem that Chief Justice Fuller was preparing for the task of rationalization to come by suggesting that the state statute was an exercise of the police power, thus departing somewhat from the position taken in the Bowman case. But of. $i d$. at Ir 5 , where the statute appears to have been regarded as a regulation of commerce. See also id. at Irg, where occurs a passage which seems to imply that Congress could change the result in the Bowman case by "reclassifying" the state statute as an exercise of the police power.

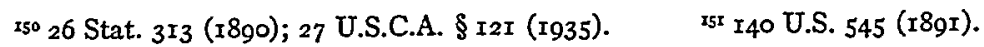


tionalization of this result as drawn from the opinion of Chief Justice Fuller runs something as follows: the power of Congress to regulate interstate commerce as to subjects national in nature is exclusive. ${ }^{\mathrm{I52}}$ The police power of the states is concurrent with the commercial power of Congress in all cases, subject of course to being superseded by an exercise of the federal power. ${ }^{153}$ In matters of national concern the silence of Congress is construed as the indication of a desire that such matters be free of all regulation, and this "will" of Congress supersedes all inconsistent state statutes even though enacted under the concurrent police power. ${ }^{154}$ Hence there is no question of delegation of power, or of reviving an unconstitutional statute. The Wilson Act merely removed an "impediment" which had rendered the state statute inoperative, just as the repeal of a statute forbidding state action would do. ${ }^{\mathrm{x} 5}$

It is submitted that this rationalization is basically unsound. If the commerce clause of the Constitution imposes no restraints on the police power of the states, as the opinion seems to assume, then any limitation upon the exercise of such power must be based upon the supremacy clause of Article VI which provides that "the Laws of the United States which shall be made . . . shall be the supreme Law of the Land." "r56 It is carrying things a bit too far to say that Congress is "making laws" by its very refusal to make laws, and that its unexpressed intentions and desires are the "supreme law of the land." ${ }_{557}$ It follows that there can be no warrant in the Constitution for the proposition that the silence of Congress can in any way limit or restrain the exercise of a state power..$^{x 8}$ Furthermore,

${ }_{153} I d$. at 555 .

${ }^{253} \mathrm{Id}$. at $554-7$. Gibbons v. Ogden was relied on for this proposition-the classification doctrine.

${ }^{\mathrm{T}} 4 \mathrm{Id}$. at $555^{-6}$.

2ss $I d$. at 564 . For a full discussion and presentation of this interpretation of the opinion, see Bikle, The Silence of Congress, 4I Harv. L. Rev. 200 (I927). It should be noted that the Court's reasoning would not apply to a case where the state legislation was classified as commercial regulation, as was the situation in the Bowman case (see p. 584 supra).

${ }^{256}$ Quoted in full in note 33 supra.

${ }_{57}$ Possibly Chief Justice Waite was seeking to explain away this absurdity when he said, "The power of regulation may be exercised without legislation as well as with it. By refraining from action, Congress, in effect, adopts as its own regulations those which the common law ... has provided for the government of such business." Hall v. De Cuir, 95 U.S. 485,490 (1878). Justice Story had thrown out a similar suggestion in The Chusan, 2 Story 455, 465, Fed. Cas. no. $27 \times 7$ (C. C. Mass. 1843). Even so, the difficulty remains, since the common law cannot be the supreme law of the land until Congress "makes" it such by affirmative action.

${ }^{\text {rs }}$ The statement is not intended to cast any doubt on the "occupation of the field" doctrine (see note I2 supra). Even in that case the restraint on state power is based on negative inferences drawn from the statute of Congress. 
this rationale would deny any effect to a federal statute purporting to permit commercial regulation by the states of matters held by the Court to be of national interest, the very situation presented in Whitfield v. Ohio. ${ }^{\text {s59 }}$

Moreover, the practical difficulty involved in trying to ascertain what Congress intends when it stands silent is so great that the above rationalization is patently unreal as a description of the judicial process of deciding a case like Leisy v. Hardin. The "psychoanalysis"r6o of Congress is a perilous venture when that body speaks ${ }^{16 \mathrm{r}}$ and a hopeless task when it is silent. It would seem that the only sensible course is to hold that when Congress says nothing it means what it says.

An alternative rationalization might be developed from the statement in the opinion that Congress can divest articles of their character as subjects of interstate commerce at a moment earlier than the sale in the original package. ${ }^{162}$ Of course, it cannot be intended that Congress can finally draw the line between interstate and internal commerce, since that would imply that Congress could vary its own power, as well as that of the states, at will. The statement might be construed to mean that Congress can remove the immunity from state action enjoyed by an article moving in interstate commerce. ${ }^{163}$ This, however, amounts to saying that Congress can restore to the states powers impliedly denied to them by the Constitution. If the Constitution excludes state power to forbid the importation of liquor because it is an article moving in interstate commerce, it is difficult to see how Congress could confer that power even if it were to prohibit all interstate movement of liquor.

Before attempting to devise a rationalization of the decision in the Rahrer case which will be consistent with the accepted doctrines of the Supreme Court, it will be helpful to consider some recent developments in those doctrines.

${ }^{159} 56$ Sup. Ct. 532 (1936). See p. 557 supra, and p. 590 infra.

${ }^{60}$ United States v. Constantine, 56 Sup. Ct. 223, 228 (r935), per Cardozo, J., dissenting.

${ }^{26}$ For a famous instance in which the Court misconstrued the "voice" of Congress, see Pennsylvania v. Wheeling Bridge Co., $x_{3}$ How. (U.S.) $5 \mathrm{I} 8$ (I852); result reversed by act of Congress, same case, I8 How. (U.S.) 421 (1856).

${ }^{{ }^{62} 2}$ In re Rahrer, 140 U.S. 545, 562 (I89I). At another point the opinion speaks of Congress' allowing "imported property to fall at once upon arrival within the local jurisdiction." Id. at 564. The opinion in the Whitfield case seems to adopt this rationalization. See excerpt quoted on p. 557 supra.

${ }^{163}$ See Powell, The Validity of State Legislation under the Webb-Kenyon Law, 2 So. L. Q. II 2 (I9I7), for a discussion of this and other possible rationalizations of the decision in the Rahrer case. Professor Powell did not seem aware of the basic flaw in the silence of Congress doctrine as pointed out above. 


\section{RECENT DEVELOPMENTS}

In I9r3 Justice Hughes, in his opinion in the Minnesota Rate Cases, ${ }^{164}$ undertook to collect and classify the previous cases dealing with the negative implications of the commerce clause for the purpose of deducing therefrom the controlling principles. The fundamental principle he stated thus: "If a state enactment imposes a direct burden upon interstate commerce, it must fall regardless of Federal legislation." "I65 The doctrine of the Cooley case was also reaffirmed, ${ }^{166}$ as was the classification doctrine in a limited form. ${ }^{167}$ Apparently the "direct burden" test was regarded as the equivalent of that applied under the Cooley doctrine, ${ }^{168}$ although the two are, in theory, based on quite different grounds and may conceivably lead to opposite results in some cases. ${ }^{169}$ The Cooley doctrine looks to the subject-matter of the regulation; the "direct burden" doctrine to the incidence and effect of the regulation upon the conduct of interstate commerce.

The emphasis placed on the "direct burden" test was bound to further weaken the effect of the classification doctrine which, as has been seen, had already suffered extensive curtailment in the State Freight Tax, ${ }^{170}$ Henderson, ${ }^{\text {7x }}$ and Boreman ${ }^{172}$ cases. It focuses attention on the effect of the state legislation rather than upon the motive of the legislature. This tendency was carried to the extreme in Di Santo v. Pennsylvania ${ }^{\mathrm{T} 73}$ wherein the Court held unconstitutional a statute requiring steamship ticket

${ }^{26}+230$ U.S. $352,396-412$ (I913).

${ }^{365} \mathrm{Id}$. at 396 . See p. $5^{82}$ supra, for the origin of this doctrine.

${ }^{66}$ Minnesota Rate Cases, 230 U.S. 352, 399-400 (I9r3).

${ }^{167}$ Id. at 406-8. The states were conceded to have power to forbid the importation of articles dangerous to health, and those susceptible of fraudulent disposition (id. at 408), but not of "legitimate articles of commerce" such as liquor (id. at 40r) where the danger presumably is to morals. The taxing power was grouped with the commercial power and definitely put outside the scope of the classification doctrine (id. at $4 \infty$ ).

${ }^{108} \mathrm{Id}$. at: 400 .

${ }^{169}$ E.g., the decision in Gilman v. Philadelphia, 3 Wall. (U.S.) $7 \mathrm{r}_{3}$ ( 1866 ), that the erection of a bridge across a navigable stream was within the state's power because the subject was suited to diverse regulation, might have gone the other way if the destruction of plaintiff's carrying business had been the point of approach.

${ }^{770}$ P. 58т supra. $\quad{ }_{172}$ P. 582 supra. $\quad{ }_{172}$ P. 584 supra.

${ }_{773} 273$ U.S. 34 (I927). Holmes, Brandeis, and Stone, JJ., dissented in opinions by the latter two. Cf. Plumley v. Massachusetts, 555 U.S. $46 \mathrm{I}$ (I894). 
agents to be bonded to protect the public against fraud. Justice Butler stated the basis of decision:

A state statute which by its necessary operation directly interferes with or burdens foreign commerce is a prohibited regulation and invalid, regardless of the purpose with which it was passed. ... . Such legislation cannot be sustained as an exertion of the police power of the State to prevent possible fraud. ${ }^{.74}$

On the other hand, the Supreme Court has more recently relied upon the classification doctrine to uphold a state regulation which directly burdened interstate commerce. In Bradley v. Public Utilities Commission, ${ }^{175}$ an order denying permission to operate as an interstate motor carrier was upheld on the ground that the purpose of the denial was to prevent dangerous congestion on the highway. Buck v. Kuykendalli16 was distinguished on the ground that there the purpose of the refusal was to prevent competition with existing carriers, a motive rendering the regulation "commercial."

In this connection the stress placed upon the purpose of the legislation in Baldrein v. Seeligiz7 is significant. Indeed the opinion in that case carries the restrictive aspect of the classification doctrine further than ever before. According to the language of Justice Cardozo, quoted at the outset of this paper, ${ }^{178}$ all state regulations enacted with the purpose and having the effect of suppressing extrastate competition are unconstitutional regardless of the incidence of the regulation. Thus, in that case not only was the restriction upon the sale of imported milk in original packages held invalid, but that upon the sale in broken packages as well, a transaction uniformly classed as internal commerce. ${ }^{179}$ The supposed intent of the framers of the Constitution to remove all interstate trade barriers was chiefly relied upon, ${ }^{180}$ although some attempt was made to find a "direct burden" because of the legislative intent to curtail interstate commerce. ${ }^{\text {I8r }}$ The general tenor of the opinion is similar to that of Justice Miller in Woodruff v. Parham..$^{82}$ No mention was made of the silence of Congress.

In spite of the broad statements and emphatic language used in the Seelig case, the Supreme Court in Whitfield v. Ohio ${ }^{183}$ held that a state can

174 Id. at 37 . 175289 U.S. 92 (1933).

${ }_{176}{ }_{267}$ U.S. 307 (I925), holding invalid a similar state order.

177294 U.S. 5 II (I935). ${ }_{178}$ P. 556 sitpra.

${ }^{279}$ In the trial court the latter regulation was upheld on this ground, although the former was held invalid. Seelig v. Baldwin, 7 F. Supp. 776, 779 (N.Y. I934), per L. Hand, J. The opinion points out the inconsistency of the classification doctrine with the "direct burden" doctrine.

${ }^{180}$ Baldwin v. Seelig, 294 U.S. 5rI, 522-3 (I935).

${ }^{185} I d$. at 522 . This seems to be a departure from the objective character of that test. ${ }^{182}$ See p. 578 supra. ${ }^{283}{ }_{56}^{6}$ Sup. Ct. 532 (1936). 
forbid the sale of imported convict-made goods in broken packages and, with the consent of Congress, in original packages. ${ }^{84}$ Putting the federal statute to one side for the moment, how can these cases be reconciled? Not upon diversity in the purpose of the legislation, since in each case it was designed to protect local producers against extrastate competition of the same type-underselling because of lower production costs; nor upon the humanitarian ground of discouraging the exploitation of forced labor for private profit, since that can be no more the legitimate concern of the state of destination than would be the employment of any persons at less than a living wage; nor yet upon a difference in the directness of the burdens. There is, however, one method ${ }^{\mathrm{I85}}$ of explaining the decisions, if not of reconciling the opinions.

There is one very significant difference in the facts of the two cases. The business of producing and distributing milk is an industry of the first rank in this country, whereas that concerned with convict-made goods is insignificant. If New York were permitted to tinker with the distributing end of the milk marketing system, severe dislocations of the entire system might follow causing loss to thousands of dealers and producers in other states who had invested their labor and capital in the faith that the free interstate marketing system would continue. No consequences of comparable gravity can flow from the action of Ohio. In short, the national interest in securing to the milk industry a free nationwide market is vastly greater than that in affording similar protection to prison industries. The former is deemed sufficient to override the legitimate and praiseworthy interest an individual state may have in improving the economic position of its producers; the latter is not. May not the Court really, underneath all the doctrines and formulas, be deciding these commerce clause cases by balancing conflicting interests, the national against

${ }^{184}$ See quotation on p. 557 supra.

${ }^{885} \mathrm{~A}$ distinction might be drawn on the ground that the New York statute discriminates against imported goods whereas the Ohio statute does not. The purchase of milk in Vermont and its importation into New York were entirely lawful acts. Hence the title of the importer in New York was as perfect as that of an owner of milk produced in that state who bad paid the statutory price therefor. Yet the former was forbidden to sell his milk and the latter permitted, a discrimination which, it could be urged, was based on the origin of the goods. The Ohio statutes, on the other hand, forbid all persons to sell convict-made goods, of whatever origin, upon the open market. The distinction disappears, however, if the New York statutes are read as forbidding the sale of all milk, of whatever origin, whose producers received less than the statutory price.

Incidentally one wonders why counsel for Whitfield did not rely on the equal protection clause. Is it reasonable to classify the shirts on a merchant's shelf, which are of identical kind and quality, according to the conditions under which they were manufactured in other.states? 
the local? ${ }^{186}$ And would this not be the most desirable approach after all? ${ }^{187}$ The Court's failure openly to espouse it as a rule of decision is not surprising. That tribunal is naturally somewhat reluctant to hold itself out as the director of major economic policies when it already is in a position to exercise a large degree of discretion by selecting that one of the diverse and mutually inconsistent doctrines at hand, which will lead to the result deemed best under the circumstances. Then there are fundamental principles of constitutional interpretation to be reckoned with, as well as the various subordinate doctrines, each supported by scores of Court opinions over many years.

\section{A POSSIBLE SOLUTION}

It is submitted that there is a way out which will not involve an outright abandonment of these intrenched doctrines and which will not stray from accepted principles of constitutional interpretation. It involves, of course, the creation of a new doctrine, but one more flexible than the old and hence more workable.

The basic proposition would be that of the Cooley case, that the commerce clause of itself excludes some state action in relation to certain subjects, but not all state action as to all subjects. Instead of considering only the subject-matter of the regulation, the inquiry would extend to a consideration of all the circumstances of the case. The test would be that already suggested-which interest, that of state or nation, should prevail. ${ }^{188}$ This involves no greater departure from sound constitutional interpretation than did the Cooley case itself. The long step was taken in I852 when the Supreme Court assumed the power to apply either the exclusive or the concurrent theory of interpretation in its discretion.

${ }^{866}$ The above suggestion would go far to explain the decision in Silz v. Hesterberg, 2 II U.S. 3 I (I908), that a state may prohibit the possession of lawfully-acquired, imported game birds during the closed season on such birds in that state, a decision which has been hard to square with accepted doctrine. See Baldwin v. Seelig, 294 U.S. 5II, 525 (I935). Cf. Bayside Fish Flour Co. v. Gentry, $5^{6}$ Sup. Ct. $5^{13}$ (1936).

Perhaps the suggestion also provides the key to reconciling Geer v. Connecticut, I6I U.S. 5I9 (I8g6), upholding a state export embargo on game birds lawfully killed, with FosterFountain Packing Co. v. Haydel, 278 U.S. I (rg28), contra as to export embargo on unshelled shrimp; and Hudson County Water Co. v. McCarter, 209 U.S. 349 (Ig08), upholding export embargo on river water, with Pennsylvania v. West Virginia, 262 U.S. 553 (1923), contra as to export embargo on natural gas. See Frankfurter and Freund, Interstate Commerce, 8 Soc. Sci. Ency. 220, 222, 226 ( $(932)$.

${ }^{287}$ This suggestion is neither original nor novel. See the dissenting opinion of Stone, J., in Di Santo v. Pennsylvania, 273 U.S. 34, 43-5 (1927), quoted in part in note I27 supra; argument of counsel in Baldwin v. Seelig, 294 U.S. 5II, 5I3 (I935).

${ }^{213} \mathrm{Cf}$. the language of the opinion in the Cooley case, "whatever subjects of this power are in their nature national." (See p. 576 supra, for context.) 
The next step would be finally to abandon the classification doctrine as an ultimate determinant, and transform it into a method of approach. The purpose of the state legislation should be an important factor to be considered in determining whether in a given case the interest of the state should or should not prevail. Thus a statute intended to prevent the spread of disease might be upheld in a situation where a similar regulation based on any other motive might be invalidated. In cases where the national interest is strong, however, and the danger to health slight, the federal power might well be held exclusive. On the other hand, as in the Whitfield case, the fact that the motive of the state legislature is to further the economic interests of its people should not preclude a finding of state power. Because of the absence of a legitimate state interest, the result in a case involving discriminatory state legislation would be the same as that now reached.

In much the same way the incidence of the burden of the regulation, whether direct or indirect, could be considered as a factor in reaching the final determination. This particular approach has been most frequently applied in taxation cases in the past. It is useful in such cases but it should not be the only factor considered. Weight would also be given, under the proposed doctrine, to the revenue needs of the state and to the possible injustice of casting an unequal tax load on intrastate competitors.

No significance, of course, would be attached to the silence of Congress, for reasons pointed out above. But not so as to the "voice of Congress." The Whitfield case indicates that the expressed intention of Congress to permit state action does have a practical effect. The next problem is to square this result with theory. This leads to the second part of the suggested solution.

As has already been seen, the silence of Congress can be no impediment to state action; hence in the absence of any federal legislation, all limitations on the states must be derived directly from the Constitution. But, if so, how explain the decision of the Rahrer case? Can Congress remove a constitutional limitation? No, but Congress can alter other factors so that certain state action no longer falls within the constitutional prohibition.

We start with the proposition that the commerce clause is to be construed to exclude directly state power in situations where the national interest in having interstate traffic free from state restraints is stronger than the local interest in question. The next proposition is that Congress is the proper body to balance these conflicting interests. It follows that. when Congress assents to certain state action under specified circumstances, it amounts to a finding that in that particular situation the state 
interest is dominant, a finding which the Supreme Court should and will follow in subsequent cases. ${ }^{189}$ In the silence of Congress the Court, perforce, must balance the interests according to its view of sound policy, just as a court must decide ordinary causes in the absence of applicable legislation. In the former case, as in the latter, when the legislature does announce a different policy, it should prevail as the policy of the nation.

There is no difficulty in reconciling this solution with accepted constitutional principles. Congress has the undisputed power to restrict the area in which state action is permitted by the Supreme Court. Why can it not expand that area as well? The objection that Congress cannot define the limits of its own power is not in point; ${ }^{\text {;90 }}$ Congress is regulating subjects which are conceded to be within its power. Nor, under the suggested interpretation of the commerce clause, is Congress delegating power to the states. It is determining the national policy, an ordinary and proper legislative function. The Constitution, according to the proposed view, prohibits state action which is in conflict with national policy; a change in that policy may result in removing the restraint, but it does not alter the interpretation of the Constitution itself.

Another possible objection is that the Constitution itself contemplates and demands uniformity of commercial regulations in regard to certain important matters-the argument which prevailed with the Court in respect to the admiralty jurisdiction of Congress. ${ }^{191}$ To this two answers can be made. In the first place, there is no warrant for this contention in the language of the Constitution. The presence of express requirements of uniformity in relation to the taxing, naturalization, and bankruptcy powers, ${ }^{\mathrm{x} 92}$ and of equality of treatment in the regulation of ports ${ }^{\mathrm{x} 93}$ raises an inference that no such limitations on the general commercial power were intended. ${ }^{194}$ Moreover, Congress is expressly authorized to permit the

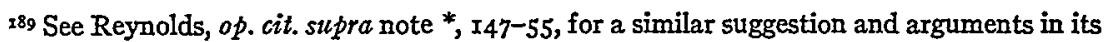
support.

${ }_{190}$ Nevertheless it has been seriously advanced. See Bikle, op. cit. supra note $\mathrm{x}_{55}$, at $2 \mathrm{I}_{3}$. Cf. Powell, op. cit. supra note 163 , at $\mathrm{r}_{35^{-}} 6$.

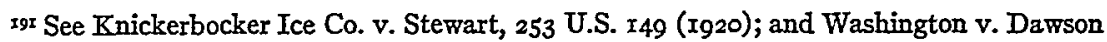
\& Co., 264 U.S. 2 I9 (I924), holding that Congress cannot permit state workmen's compensation acts to be applied to maritime workers. For criticism of the result, see Morrison, Workmen's Compensation and the Maritime Law, 38 Yale L. J. 472, 477-83 (r929).

${ }_{922}$ U.S. Const., art. I, $\$ 8$, cl. I, 4 . $\quad{ }_{93}$ U.S. Const., art. I, $\$$ 9, cl. 6.

194 Chief Justice Marshall's statement on this point is classic. "It is the power to regulate; that is, to prescribe the rule by which commerce is to be governed. This power, like all others vested in Congress, is complete in itself, may be exercised to its utmost extent, and acknowledges no limitations, other than are prescribed in the constitution. These are expressed in plain terms." Gibbons y. Ogden, 9.Wheat. (U.S.) I, rg6 (I824). 
imposition of customs duties by the states, ${ }^{x 95}$ thus leading to diversity in respect of a matter in which Congress itself must act uniformly. Secondly, the Supreme Court in Clark Distilling Co. v. Western Maryland R. Co. ${ }^{\text {196 }}$ held that the commercial power of Congress was not subject to the requirement of uniformity.

From the practical standpoint the arguments in favor of the voice of Congress doctrine as here outlined far outweigh those to the contrary. The regulation of commerce, like taxation, is a "practical" matter-by which is meant that the effect on individuals is so great, largely because of the tendency of competitive forces to amplify any inequality in the effect of the legislation, that logic alone is not a safe guide. According to the suggested "balance of interest" doctrine, the "correct" delimitation of the sphere of state power requires a knowledge of a tremendous number and variety of facts, and involves a series of intelligent choices between alternative systems of governmental control. True, a court can handle this problem-indeed, it must when Congress stands silent. But Congress is a far more suitable body to perform this function. It is in an immensely superior position in respect of gathering facts and forecasting future developments. More important, it is the policy-formulating branch of the government. Congress has always actively and intelligently sought to guide the commercial development of the nation by affirmative legislative action. It has helped certain industries by protective tariffs, loans, and subsidies; it has hampered others by burdensome special taxes. The determination of the extent to which a given commercial activity should be free from state regulation and taxation falls in the same general category-it too may make or break. Again, Congress can, by drawing the line with more precision and in greater detail than can the Supreme Court, which deals of necessity in generalities, eliminate much of the uncertainty in this field of constitutional law, a gain of great importance to both state governments and private industry. ${ }^{197}$

Against these arguments can be set the contention that diversity in the regulation of certain commercial activities would be so inimical to the national welfare that even Congress should not be able to sanction it. This argument assumes that Congress may at some future time err so grossly in determining where the balance of interest lies that the Supreme

${ }_{395}$ U.S. Const., art. r, $\S$ Io, cl. 2. Set out on p. 562 supra.

${ }^{196} 242$ U.S. 3II, 326-3I (I9I 7), holding valid a federal statute forbidding the carriage of liquor into any state for use in violation of the laws thereof. For a critical discussion of this case, see Powell, op. cit. supra note I63.

${ }^{297}$ See International News Service v. Associated Press, 248 U.S. 215, 264-7 (Igr8), per Brandeis, J., dissenting. 
Court will be convinced of the mistake. So far the Supreme Court has been willing to follow the lead of Congress, even when contrary to its own previous-albeit somewhat hesitant-conception of sound policy, as in the liquor cases. What it would do in the assumed case cannot be predicted. It is not unlikely that the Court will have an opportunity to clarify its position in the relatively near future. A bill to permit state taxation of interstate sales transactions has been proposed; ${ }^{198}$ and the Whitfield decision invites a new attack on the child labor problem along the lines of the Hawes-Cooper Act. ${ }^{199}$

The negative implications of the commerce clause have undergone a most intricate and interesting evolution. The variety of doctrines which have been advanced from time to time by members of the Supreme Court and the decided shifts in the position taken by that tribunal are truly remarkable. Generally speaking, the trend from the beginning has been toward limiting the scope of state power, but there has been a decided change in the conceptions of public policy which have led the Court to pursue this course. Originally, the Supreme Court felt called upon to curb the states in order to protect the prerogatives of Congress; Marshall, Story, and McLean were motivated by a desire to build up a strong central government. After the Civil War, the chief objective of the Supreme Court seems to have been, and to be, the elimination of all state interference with interstate commerce. The ideal now is freedom of trade; the merchant has supplanted Congress as the object of the Court's solicitude. The final development has been the appearance of Congress as an ally of its onetime rivals, the state legislatures.

It may well be that the future disputes over the negative implications of the commerce clause will center largely about the extent of the power of Congress to permit state regulation. It will be somewhat ironical if the arguments of Webster and Story, which were advanced to prevent the states from trespassing upon the domain of Congress, are used to deny to Congress the power to permit the states to enter.

${ }^{198}$ See Perkins, The Sales Tax and Transactions in Interstate Commerce, r2 N.C. L. Rev. 99 (I934); Lowndes, State Taxation of Interstate Sales, 7 Miss. L. Jour. 223 (I935).

${ }^{199}$ At this point the well-known case of Hammer v. Dagenhart, 247 U.S. 25 I (rgr8), appears as a possible barrier. Will the Supreme Court permit Congress and the states acting in concert to do what it has held that neither Congress nor the states (cf. Baldwin v. Seelig, supra pp. 556, $590)$ can do alone? This interesting problem, involving as it does the affirmative interpretation of the commerce clause, lies beyond the scope of this paper. For a discussion of Whitfield $v$. Ohio from this viewpoint, see note, Power of Congress to Subject Interstate Commerce to State Regulation, post, p. 636; 49 Harv. L. Rev. 466 (1936). 